\title{
Microfinance and Gender: Is There a Glass Ceiling in Loan Size?
}

\section{I sabelle Agier and Ariane Szafarz}

Microfinance institutions serve a majority of female borrowers. But do men and women benefit from same credit conditions? This paper investigates this issue by presenting an original model and testing its predictions on an exceptional database including 34,000 loan applications from a Brazilian microfinance institution over an eleven-year period. The model considers a lender that offers standardized loan contracts with a fixed interest rate, which is common practice in microfinance. It demonstrates that biased loan attribution may lead to three different outcomes, depending on the bias intensity: 1) denial of all applications from a given group, 2) a "glass ceiling" effect, namely loan downsizing of the largest projects from a given group, or 3) no impact. The empirical analysis detects no gender bias in approval rate, but uncovers a glass ceiling effect hurting female applicants. Moreover, this effect is insensitive to the credit officer's gender. In conclusion, the good news is that the microfinance practice does ensure a fair access to credit. The bad news is the presence of a glass ceiling faced by female entrepreneurs with larger projects.

Keywords: Microcredit, Microfinance, Discrimination, Loan Size, Loan Approval, Gender

JEL Classifications: O16, D82, J33, L31.

CEB Working Paper Nº 10/047

September 2010 


\title{
Microfinance and Gender: Is There a Glass Ceiling in Loan Size?*
}

\author{
Isabelle Agier ${ }^{\dagger}$ \\ Ariane Szafarz
}

This version: September 17, 2010

\begin{abstract}
Microfinance institutions serve a majority of female borrowers. But do men and women benefit from same credit conditions? This paper investigates this issue by presenting an original model and testing its predictions on an exceptional database including 34,000 loan applications from a Brazilian microfinance institution over an eleven-year period. The model considers a lender that offers standardized loan contracts with a fixed interest rate, which is common practice in microfinance. It demonstrates that biased loan attribution may lead to three different outcomes, depending on the bias intensity: 1) denial of all applications from a given group, 2) a "glass ceiling" effect, namely loan downsizing of the largest projects from a given group, or 3) no impact. The empirical analysis detects no gender bias in approval rate, but uncovers a glass ceiling effect hurting female applicants. Moreover, this effect is insensitive to the credit officer's gender. In conclusion, the good news is that the microfinance practice does ensure a fair access to credit. The bad news is the presence of a glass ceiling faced by female entrepreneurs with larger projects.

Keywords: Microcredit, Microfinance, Discrimination, Loan Size, Loan Approval, Gender JEL codes: O16, D82, J33, L31.

*The authors thank Juliano Assunção, Marcella Corsi, Bert d'Espalier, Isabelle Guérin, Valentina Hartaska, Marek Hudon, Marc Labie, Anaïs Périlleux, Koen Rossel-Cambier, Jean-Michel Servet, Øystein Strøm, Rodrigo Soares, and the participants to the Third International Workshop on Microfiance (Groningen, August 2010) for helpful discussions and suggestions.

${ }^{\dagger}$ Pontifical Catholic University of Rio de Janeiro, Department of Economics, Email: isabelleagier@gmail.com

${ }_{\ddagger}^{\ddagger}$ Université Libre de Bruxelles (ULB), SBS-EM, Centre Emile Bernheim, and CERMi, Email: aszafarz@ulb.ac.be
\end{abstract}


"It is one of the injustices of the way that society is organized in Bangladesh that extremely able women, even those from better-off households, are unable to realize their entrepreneurial potential because their gender acts as a barrier to gaining access to the necessary resources. Men, even poor men, have always had more choices in terms of accessing economic opportunities than women from an equivalent class" Kabeer (2001) (p. 83)

\section{Introduction}

Microfinance institutions (MFIs) offer tiny loans to poor entrepreneurs, among which a majority of women (according to Daley-Harris (2009), in 2007 more than $70 \%$ of MFIs' clients were women $\left.{ }^{1}\right)$. While this evidence is widely acknowledged in the literature (Armendáriz and Morduch, 2010), few papers examine whether male and female borrowers benefit from same credit conditions. This paper investigates this issue by proposing both a novel conceptual framework and an empirical analysis based on an exceptional database encompassing 34,000 loan applications from a Brazilian MFI.

Because of its focus on women, common wisdom views microfinance as some sort of spontaneous affirmative action. Nevertheless, things are less obvious than they look. Indeed, the fact that women benefit from smaller loans than men might be due to different causes. On the one hand, women in developing countries are poorer than men, ${ }^{2}$ and their entrepreneurial projects have smaller scope. On the other hand, as observed by, e.g., Storey (2004) and Alesina, Lotti and Mistrulli (2008), smaller loans could result from biased loan granting. ${ }^{3}$ This paper aims to clarify this question by comparing loan attribution to male and female applicants with similar creditworthiness characteristics.

The issue at stake relates to two different streams of literature dealing with women empowerment in microfinance, and discrimination in lending, respectively. Firstly, the link between microfinance and women empowerment has been thoroughly examined. Several authors have acknowledged the merits of microfinance on increasing women's bargaining power and social capital (Hashemi, Schuler and Riley, 1996; Pitt, Khandker and Cartwright, 2006). However, in line with Goetz and Sen Gupta (1996), recent studies on intrahousehold relations in India (Garikipati, 2008; Guérin et al., 2009) have chal-

\footnotetext{
${ }^{1}$ This rate reaches more than $80 \%$ for poorest clients.

${ }^{2}$ According to ILO (2009), $75 \%$ of poverty worldwide is female.

${ }^{3}$ Mayoux (2002) mentions the "danger of "ghetto-ising" women within small loan programmes".
} 
lenged the impact of microfinance on women empowerment by exhibiting that lending to women may increase their financial vulnerability. Trying to reconcile both views, Kabeer (2001) observes that the positive evaluations focus on access to credit while the negative ones focus on loan use. She concludes by emphasizing that the reasons for lending to women go far beyond empowerment. Scrutinizing the sector's lending practices may thus bring valuable insights to this lively debate.

Secondly, because of legal requirements, ${ }^{4}$ discrimination in lending has been scrutinized mainly in US mortgage lending (Munnell et al., 1996; Turner and Skidmore, 1999; Han, 2004) and small business credit industry (Blanchflower, Levine and Zimmerman, 2003; Cavalluzzo and Cavalluzzo, 1998; Cavalluzzo and Wolken, 2005). In mortgage lending, evidence shows that black applicants face the worst denial rate (Schafer and Ladd, 1982; Ross, 2000) while female applicants are subject to disparate treatment (Ladd, 1998). Refining the existing econometric methodology, Blanchard, Zhao and Yinger (2008) also find evidence of credit discrimination against black-owned and Hispanicowned businesses, but not against white women. However, these authors do not separate black and Hispanic women from men, which makes it difficult to globally assess discrimination against female applicants. Stereotypes thus seem to survive the enforcement of the US Equal Credit Opportunity Act.

Outside the US, discrimination in lending has been scarcely studied. Storey (2004) shows that, in Trinidad and Tobago, loan applications from Afrodescendant small-business owners are more likely to be denied than others. A study on Italian microfirms and self-employed individuals by Alesina, Lotti and Mistrulli (2008) emphasizes that women pay higher interest rates although they exhibit a slightly better credit history. Additional evidence on gender discrimination in Italian small business lending is provided by Bellucci, Borisov and Zazzaro (2009). Buvinic and Berger (1990) and Fletschner (2009) show that women keep being more credit-rationed than men by MFIs.

Importantly, the notion of discrimination in lending considered here is purely taste-based (Becker, 1971) and independent from any economic motivation. As social psychologists claim (Fein and Spencer, 1997; Kunda and Sinclair,

\footnotetext{
${ }^{4}$ The US legal framework against discrimination in lending notably includes the Fair housing Act of 1968, the Equal Credit Opportunity Act (ECOA) of 1974 and the Home Mortgage Disclosure Act (HMDA) of 1975. In 1989, the Congress amended the former HMDA and imposed to lenders to report the race and ethnicity of their loan applicants. Wide disparities in the loan denial rates were subsequently exhibited by the Boston Federal Reserve Bank using the HMDA database. Based on denial rates, Munnell et al. (1996) show that ethnic minorities (African-Americans and Hispanic-Americans) were facing much larger loan rejection rates than white applicants with similar creditworthiness.
} 
1999), stereotyping and prejudice are common features in human behavior.

Our first contribution is theoretical. It draws upon the specific microcredit lending methodology. Typically, to keep their costs low MFIs offer standardized loan contracts with a fixed interest rate, and hence use a credit rationing methodology (Morduch, 1999). In our model, loans are granted by a possibly biased lender who offers fixed interest loans and tailors loan size to the applicant's perceived creditworthiness. In this context, Beckerian discrimination (Becker, 1971) may lead to three different outcomes, depending on the intensity of the lender's bias: 1) denial of all applications from the discriminated-against group, 2) a glass ceiling (Kanter, 1993), i.e., a gap hurting the largest projects from the discriminated-against group, and 3) no impact.

Our second contribution consists in empirical assessment based on unique data provided by a Brazilian microfinance institution, encompassing 34,000 loan applications over an eleven-year period. To our best knowledge, this paper is the first one to export the discrimination-in-lending approach to microfinance. Moreover, as the database includes not only all applicants' characteristics used as screening devices by credit officers, but also the amount requested by each loan applicant, partial-least-square estimation is used to avoid multicollinearity.

The estimation results are threefold. Firstly, we detect no discriminatory practice in the approval rate, but uncover a gender gap in loan size. Under similar circumstances, women face harsher loan conditions than men. Secondly, we confirm the presence of a glass ceiling effect, namely largest female projects face the highest penalty. Lastly, we show that these findings are insensitive to the credit officer's gender.

In conclusion, the good news is that the microcredit practice does indeed ensure a fair access to credit, which is an exceptional achievement given the persistence of discrimination in lending in developed countries. The bad news is the existence of a glass ceiling endured by the most ambitious female entrepreneurs. Therefore, our results are consistent with the mitigated conclusions reached in the literature on women empowerment through microfinance.

The paper is organized as follows. Section 2 presents the theoretical model. Section 3 describes the database. Section 4 investigates the impact of gender on loan approval and loan size, taking into account a large spectrum of control variables. The presence of a glass ceiling in loan size is examined in section 5. Section 6 scrutinizes loan size determination by male and female credit officers separately. Section 7 concludes. 


\section{The Model}

The pool of loan applicants is denoted by $P$. Each applicant, $(x, g) \in P$, is characterized by two independent variables: creditworthiness, $x \in X$, and group identity, $g \in\{F, M\}$.

The risk-neutral MFI delegates screening and loan allocation to a credit officer who is possibly biased against applicants from group $F$. As the model formalizes taste-based discrimination, not statistical discrimination, the information is symmetric, at least at the credit officer's level. ${ }^{5}$

The model has one period and all loans are offered with the same interest rate $^{6} r$. At time 0 , the credit officer receives a loan request from applicant $(x, g)$, and subsequently allocates a loan of size $B=B(x, g)$ (equal to zero, in case of denial) by maximizing expected profit, $E[W(x, g)]$, which equals expected future reimbursement minus costs.

The costs include the MFI's cost of capital $r_{0}<r$, and the agent's psychological cost associated to serving $F$ applicants: $\delta(g)$, with $\delta(M)=0$ and $\delta(F)=\delta \in[0,1]$. The credit officer's maximization problem reads:

$$
\underset{B \geqslant 0}{\operatorname{aax}} E[W(x, g)]=E[R(B, x)]-B\left(1+r_{0}+\delta(g)\right)
$$

where $R(B, x)$ is the stochastic gender-independent reimbursement from borrower $(x, g)$ for a loan of size $B$, and $E[$.] represents the expectation operator. Given the objective function in equation (1), applicant $(x, F)$ is likely to receive a smaller loan than applicant $(x, M)$ in order to compensate for the cost penalty resulting from the officer's bias.

At time 1, the client reimburses according to his/her current business revenue. We assume the existence of a penalty sufficiently high to deter strategic default ${ }^{7}$. The revenue in period 1 , denoted by $y$, is stochastic. For the sake of simplicity, we assume that only two values are possible for $y$, depending on the state of the nature: a low value, $y$, and a high value, $\bar{y}$. Borrower $(x, g)$ is characterized by probability $\pi(x)$ to generate the low value $y$ in the following

\footnotetext{
${ }^{5}$ At the MFI level (not considered in the model), information asymmetry is more likely given that MFIs are highly decentralized. Discriminatory practice could then remain undetected by the MFI's stakeholders who do not observe all clients' characteristics, leading to a typical agency problem.

${ }^{6}$ This is a common practice in microcredit institutions.Alternatively, the lending rate could be adjusted to the client's risk characteristics in $x$, but besides making the model more complicated, this would not affect much the results.

${ }^{7}$ Default in Vivacred implies that the client is nationally publicized as a "bad risk".
} 
way $^{8}$ :

$$
y(x, g)=y(x)=\left\{\begin{array}{l}
\underline{y} \text { with probability } \pi(x) \\
\bar{y} \text { with probability } 1-\pi(x)
\end{array}\right.
$$

Importantly, the borrower's reimbursement capacity depends only on creditworthiness, assumed independent from group identity. Therefore, the credit officer's bias, if any, has no economic origin. ${ }^{9}$

At time 1 , variable $y(x)$ realizes and borrower $(x, g)$ repays $R(B, x)$, that is as much as he/she can, given the situation:

$$
R(B, x)=\min \{y(x), B(1+r)\}
$$

Table 1 summarizes the six reimbursement possibilities depending on loan size $B$ and the borrower's realized revenue $(y$ or $\bar{y})$. Reimbursement is deterministic for small loans $\left(B \leq \frac{\underline{y}}{1+r}\right)$, and stochastic otherwise.

Table 1: Repayment $R(B, x)$ depending on revenue $(B)$ and loan size $(y)$.

\begin{tabular}{|c|c|c|c|}
\hline Loan size $B$ & $B \leq \frac{\underline{y}}{1+r}$ & $\frac{\underline{y}}{1+r}<B<\frac{\bar{y}}{1+r}$ & $B \geq \frac{\bar{y}}{1+r}$ \\
\hline Revenue $y$ & $B(1+r)$ & $\underline{y}$ & $\underline{y}$ \\
\hline$\underline{y}[\operatorname{prob}: \pi(x)]$ & $B(1+r)$ & $B(1+r)$ & $\bar{y}$ \\
\hline
\end{tabular}

The model is solved by backward induction. From table 1, we derive the reimbursement expected at time 0 :

$$
E[R(B, x)]=\left\{\begin{array}{ccc}
B(1+r) & \text { if } & B \leq \frac{y}{1+r} \\
\pi(x) \underline{y}+(1-\pi(x)) B(1+r) & \text { if } & \frac{\underline{y}}{1+r}<B<\frac{\bar{y}}{1+r} \\
\pi(x) \underline{y}+(1-\pi(x)) \bar{y} & \text { if } & B \geq \frac{\bar{y}}{1+r}
\end{array}\right.
$$

Given the borrower's expected reimbursement in (4), the officer's objective function writes:

$E[W(x, g)]=\left\{\begin{array}{ccc}B\left(r-r_{0}-\delta(g)\right) & \text { if } & B \leq \frac{y}{1+r} \\ \pi(x) \underline{y}+B\left[r-r \pi(x)-\pi(x)-r_{0}-\delta(g)\right] & \text { if } & \frac{\underline{y}}{1+r}<B<\frac{\bar{y}}{1+r} \\ \pi(x) \underline{y}+(1-\pi(x)) \bar{y}-B\left(1+r_{0}+\delta(g)\right) & \text { if } & B \geq \frac{\bar{y}}{1+r}\end{array}\right.$

\footnotetext{
${ }^{8}$ Parametrizing the clients according to their probability to generate low revenue is a convenient way to make expected reimbursement continuous with respect to creditworthiness. In practice, the loans are reimbursed by installments, which makes the possibility of partial repayment realistic. Indeed, the expected reimbursement, $E[R(B, x)]$, is to be interpreted as the expected present value of all future payments.

${ }^{9}$ See Han (2004) for a model where both taste-based and statistical discrimination may coexist.
} 
Three notable consequences are drawn from (5). First, if the officer's prejudice is strong enough to yield $r_{0}+\delta(g)>r$, then no $F$ applicant will ever get a loan, whatever his/her creditworthiness. Second, no loan size is larger than $\frac{\bar{y}}{1+r}$, because reimbursement is capped by $y$. Third, as the officer's objective function is continuous and piecewise linear with respect to $B$ (see figure 1), only three optimal loan sizes, $B^{*}$, are feasible: $B^{*}=0$ (no loan), $B^{*}=\underline{B}=\frac{\underline{y}}{1+r}$ (small loan), and $B^{*}=\bar{B}=\frac{\bar{y}}{1+r}$ (large loan). Therefore, to solve the officer's maximization problem, we compare the three corresponding values for $E[W(x, g)]$. Consequently, (5) simplifies to:

$$
E[W(x, g)]=\left\{\begin{array}{ccc}
0 & \text { if } & B=0 \\
\pi(x)(1+r) \underline{B}[\underline{B}-\bar{B}]+\bar{B}\left[r-r_{0}-\delta(g)\right] & \text { if } & B=\underline{\bar{B}}
\end{array}\right.
$$

The optimal loan size is thus given by:

$$
B^{*}(x, g)=\left\{\begin{array}{ccc}
0 & \text { if } & r-r_{0}-\delta(g)<0 \\
\underline{B} & \text { if } & \pi(x)(1+r)>r-r_{0}-\delta(g) \geq 0 \\
\bar{B} & \text { if } & \pi(x)(1+r) \leq r-r_{0}-\delta(g)
\end{array}\right.
$$

As $\delta(M)=0$ and $r>r_{0}$, all $M$ applicants receive a loan amounting at least to $\underline{B}$. Only $F$ applicants can face denial.

The optimal loan size for an $M$ applicant is given by:

$$
B^{*}(x, M)=\left\{\begin{array}{lll}
\underline{B} & \text { if } & \pi(x)>\frac{r-r_{0}}{1+r} \\
\bar{B} & \text { if } \quad \pi(x) \leq \frac{r-r_{0}}{1+r}
\end{array}\right.
$$

Two situations may occur to $F$ applicants. First, if the bias is so high that $\delta>r-r_{0}$, then all $F$ applicants face denial. Second, if $\delta \leq r-r_{0}$, then the officer's bias acts as an additional probability ${ }^{10}$ of low revenue. Let us define:

$$
\tilde{\pi}(x)=\pi(x)+\frac{\delta}{1+r}
$$

Then, the credit officer's optimal loan size for an $F$ applicant is:

$$
B^{*}(x, F)=\left\{\begin{array}{ccc}
0 & \text { if } & \delta>r-r_{0} \\
\underline{B} & \text { if } & \delta \leq r-r_{0} \text { and } \tilde{\pi}(x)>\frac{r-r_{0}}{1+r} \\
\bar{B} & \text { if } & \delta \leq r-r_{0} \text { and } \tilde{\pi}(x) \leq \frac{r-r_{0}}{1+r}
\end{array}\right.
$$


Table 2: Optimal loan size for $F$ applicants depending on their probability of low revenue $(\pi(x))$, and the credit officer's $\operatorname{bias}(\delta)$

\begin{tabular}{|c|c|c|}
\hline \multirow{2}{*}{ Credit officer's bias: $\delta$} & \multicolumn{2}{|c|}{ Applicant's probability of low revenue: $\pi(x)$} \\
\hline & $\pi(x) \leq \frac{r-r_{0}}{1+r}$ & $\pi(x)>\frac{r-r_{0}}{1+r}$ \\
\hline $\begin{array}{c}\delta=0 \\
\text { No bias }\end{array}$ & $B^{*}=\bar{B}$ & $B^{*}=\underline{B}$ \\
\hline $\begin{aligned} \text { Case 1: } & \delta \leq r-r_{0} \text { and } \\
& \frac{\delta}{1+r} \leq \frac{r-r_{0}}{1+r}-\pi(x)\end{aligned}$ & $\begin{array}{l}\text { No Discrimination } \\
B^{*}=\bar{B}\end{array}$ & Impossible \\
\hline $\begin{array}{ll}\text { Case 2: } & \delta \leq r-r_{0} \text { and } \\
& \frac{\delta}{1+r}>\frac{r-r_{0}}{1+r}-\pi(x)\end{array}$ & $\begin{array}{l}\text { Glass ceiling } \\
\qquad B^{*}=\underline{B}\end{array}$ & $\begin{array}{c}\text { No Discrimination } \\
B^{*}=\underline{B}\end{array}$ \\
\hline Case 3: $\quad \delta>r-r_{0}$ & \multicolumn{2}{|c|}{$\begin{array}{l}\text { Discriminatory denial } \\
B^{*}=0\end{array}$} \\
\hline
\end{tabular}

In fact, all $F$ applicants are not penalized to the same extent. The actual harm depends on the applicant's probability to generate low revenue, $\pi(x)$, and on the officer's bias, $\delta$. Table summarizes the possibilities.

If the credit officer is unbiased $(\delta=0), F$ applicants obviously get the same loan size as their $M$ counterparts. If the bias is small (case 1), the outcome is the same for $F$ applicants with low $\pi(x)$ 's. If the bias is high (case 3), loan is denied to all $F$ applicants, whatever their creditworthiness. In the middle scenario (case 2), the credit officer's bias is small enough to avoid discriminatory denial, but high enough to prevent $F$ applicants from getting $\bar{B}$. This is the typical "glass ceiling" situation where loan size equals $\underline{B}$ for all $F$ applicants, and only $F$ applicants with low $\pi(x)$ 's are hurt.

As illustrated by figure $1, F$ applicants may face discrimination whatever their creditworthiness, but the probability is smaller for those with a high $\pi(x)$ (graph on the right). Indeed, for such borrowers, the credit officer has only two possibilities: unfair denial or fair loan size, $\underline{B}$. In case 2 , fair loan size is optimal for the credit officer.

On the opposite, for $F$ applicants with a low $\pi(x)$ (graph on the left), the credit officer has three possibilities: unfair denial, unfair loan size, $\underline{B}$, or fair loan size, $\bar{B}$. Now, in case 2 , the credit officer's optimal loan size is $\underline{B}$, resulting in a discriminatory gap. Therefore, biased officers are particularly detrimental to their MFI as they downsize the loans provided to the most profitable $F$ applicants.

In summary, high bias against $F$ applicants leads to denial as the credit officer's psychological cost is too high to be compensated by expected prof-

\footnotetext{
${ }^{10}$ Actually, this number is not a probability anymore, as it may exceed one.
} 
Figure 1: Officer's objective function and optimal loan size for $F$ applicants

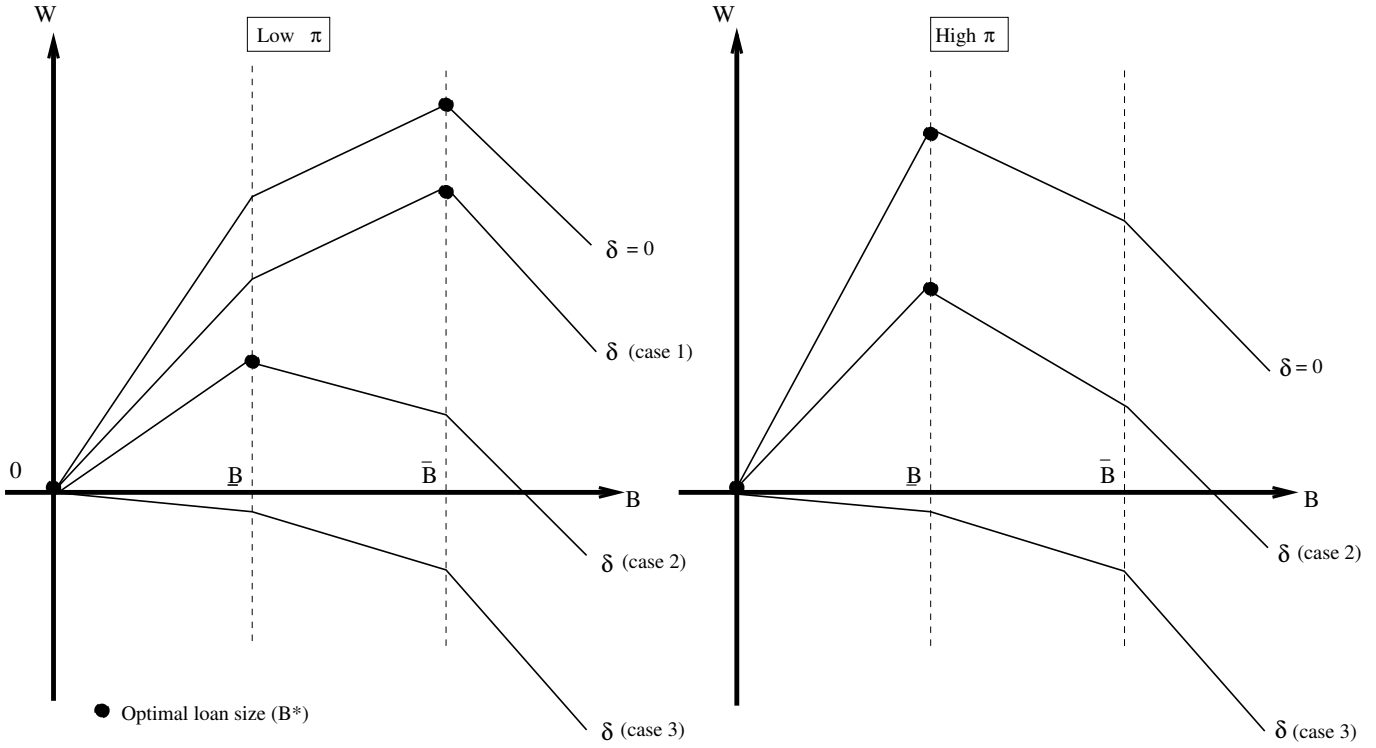

$W$ is the officer's objective function for given $\delta$ 's and $x$ 's . The unbiased officer's case $(\delta=0)$ is the benchmark.

its. When the bias is less pronounced, a trade-off appears between expected profits and the credit officer's psychological cost. As this cost is proportional to loan size, it hurts particularly more profitable applicants. Moreover, the "glass ceiling" effect appears when all $F$ applicants end up with loan size $\underline{B}$. In that situation, no increase in creditworthiness will ever make it possible for an $F$ applicant to reach the higher loan size, $\bar{B}$, which therefore remains reserved to $M$ applicants.

This result contradicts the argument by Zycher and Wolfe (1994) stating that there is more room for lending discretion in the "gray area" where the applicant's creditworthiness is not well established (in our model, this gray area corresponds to: $\left.\pi(x) \simeq \frac{r-r_{0}}{1+r}\right)$. This difference is due to the fact that our model imposes no penalty to rogue agents, which is in line with the current practice. Although incentive schemes are becoming common in MFIs (McKim and Hughart, 2005), no penalty for discriminatory behavior has, to our knowledge, ever been enforced.

Biased loan granting is thus detrimental not only to the applicants who suffer from discrimination, but also to the lending institution that misses profit opportunities because of its agent's bias. In microfinance though, no systematic investigation for biased loan allocation has been put in place yet, and there exists no regulation on that matter. However, the social orientation of most MFIs could act as a natural prevention mechanism to deter discriminatory 
practices provided that adequate monitoring instruments and/or incentives are put in place. Indeed, as shown from the survey data ${ }^{11}$ reported by Labie et al. (2010), credit officers tend to be more biased than other MFI's employees. Unfortunately, Labie et al. (2010) also emphasize that due to cost issues, internal governance mechanisms may fall short in fully eliminating discrimination. Therefore, there is room for external actors, like donors and regulatory authorities, to come up with an anti-discrimination agenda. But before drawing policy recommendation, a careful assessment of the facts is needed.

\section{Data}

Our unique database comes from Vivacred, a non-profit microcredit institution operating in Rio de Janeiro'sfavelas, for the period 1997-2007 (11 years). Vivacred provides credit to tiny and small firms located in Rio's low-income communities and neighborhoods. It focuses on urban (formal and informal) micro-businesses such as storekeepers, craftspersons, and service providers. Vivacred started its activity in 1996 in Rocinha, the largest favela in Rio. Five other branches were created since then: Rio das Pedras in 1998, Copacabana (now in Gloria) in 1999, Maré in 2000, Santa Cruz in 2002, and in the city of Macaé (Rio state) in 2004. Until 2009, Vivacred was mostly funded by the Brazilian Development Bank (BNDES). Then, Vivacred integrated the national program CrediAmigo financed by Banco do Nordeste, a Brazilian public bank.

The typical loan proposed by Vivacred has a fixed monthly interest rate of $3.9 \%^{12}$ and an additional one-shot registration fee (from 3 to $5 \%$ ) depending of the credit duration and the client's repayment history.

The dataset used in this paper contains not only the actual loan contracts, but also all applications details presented to the committee (approved or denied). For the period under consideration (1997-2007), about 41,000 loans

\footnotetext{
${ }^{11}$ The survey is about the treatment of the disabled by Ugandese MFIs.

${ }^{12}$ While this rate looks very high at first sight, it has to be understood in the Brazilian context. Over the period 1997-2007, the central bank key interest rate (celic) was between $0.89 \%$ and $2.58 \%$ a month (between $11.18 \%$ and $35.76 \%$ a year). During the same period, Banco da Mulher, a comparable non-profit institution, was offering rates between $3 \%$ and $5 \%$ a month, and Fininvest, a for-profit institution, was offering consumption loans with rates reaching $12 \%$ a month. In 2008, Vivacred was funded by BNDES (Brazilian Bank of Development) at an annual rate of $7.5 \%$ (this rate was even higher during the period 1997-2007).
} 
were solicited by 15,400 applicants, and about 32,000 loans were granted to 11,400 borrowers. Our database includes all pieces of information gathered by the six branches of Vivacred. However, we removed from the data set the applications canceled by the clients, the contracts with incomplete specifications, the loans to Vivacred's employees, and the few group loans. Therefore, the study is based on exhaustive data of 34,000 applications and 32,000 actual loans.

Detailed information is collected by Vivacred for each application. It includes the applicant's and the guarantor's personal situations and household budgets ${ }^{13}$ the business characteristics and financial statements, ${ }^{14}$ the requested amount, and the actual loan size, if offered.

Access to Vivacred's loans requires having at least six months of business activity. The application is examined by the credit committee ${ }^{15}$, which makes the final decision (acceptance or denial, and loan size) on the basis of a proposal from the credit officer in charge. Vivacred follows a flat interest rate lending methodology based on credit rationing (Stiglitz and Weiss, 1981) rather than risk-adjusted interest rates. This typical way of doing of MFIs raises ethical issues, as discussed by Hudon (2009).

Figure 2 presents Vivacred's nominal and deflated loan volume in BRL ${ }^{16}$ on a yearly basis. In 1997, microcredit was only starting in Brazil ${ }^{17}$. In 2000-2001, Vivacred experienced a deep staff shortage because of massive headhunting, yielding a decrease in new contracts.

Figure 3 depicts the evolution of average loan size in nominal and deflated

\footnotetext{
${ }^{13}$ More precisely, the information available for all clients includes: private and professional addresses, birth date, birth state, marital status, gender, dependent(s), profession, bank references, partner's ID, current account, family consumption, family external income, full credit history (as a borrower, a borrower's partner, or a guarantor). Unfortunately, the Vivacred database does not contain racial information. Actually, because of miscegenation, racial segmentation is difficult in Brazil (Sheriff, 2000). The region of origin, provided for about two-thirds of Vivacred's clients, could be taken as an imperfect proxy for race (colored people are more concentrated in northern regions). We decided to discard this imprecise information in order not to lose observations.

${ }^{14}$ Namely: location, type of activity, age, bank references, legal status, detailed assets and liabilities, expenditure and revenues, and number of employees.

${ }^{15}$ The term "credit committee", borrowed from Vivacred practice, is misleading. Actually, it refers to a single person. Depending on the requested amount, it can be the branch manager or a senior credit officer (different from the one presenting the loan application to the committee).

${ }^{16}$ BRL denotes the Brazilian currency (Real). Over the period under consideration, the BRL fluctuated between 0.270 and 0.588 USD.

${ }^{17}$ Until 2005, Brazilian authorities made no distinction between credit for consumption and for business.
} 
Figure 2: Vivacred's annual loan volume in nominal and deflated terms, and number of loans

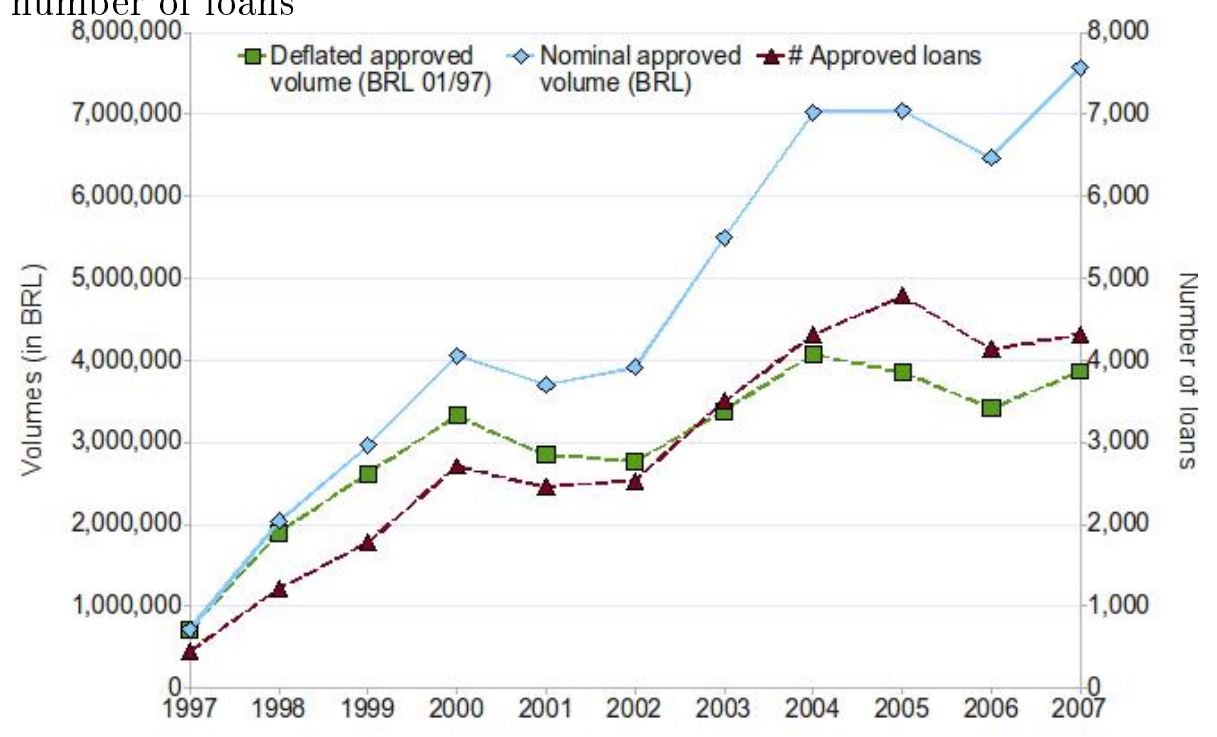

BRL. The nominal average loan size is stable over the period, making the deflated loan size decrease (from BRL 1,600 in 1997 to BRL 900 in 2007). Thus, unlike several MFIs in Latin America, Vivacred reinforced its mission fulfillment rather than experiencing a mission drift.

Figure 3: Vivacred's gross and deflated average loan size

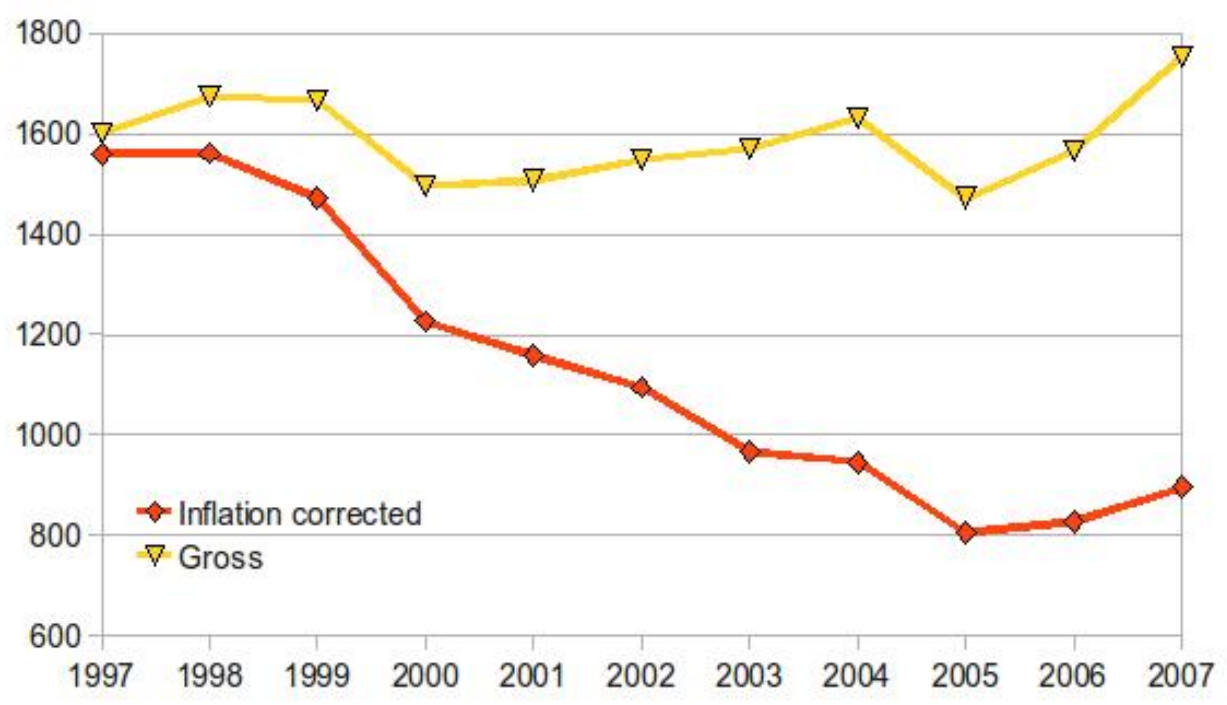

Vivacred reports the names of its defaulting borrowers to the national list 
of bad debtors (SPC), which is available for consultation to any institution supplying any kind of credit, including shops. The penalty for default is thus high. Beyond losing access to credit, those who are registered in SPC face serious trouble, for instance, getting a cell phone contract, or buying household appliances.

Table 3 provides the global and gender-disaggregated descriptive statistics for Vivacred's pool of applicants, together with a t-test for equal mean among the two groups.

Table 3: Global and gender-disaggregated descriptive statistics

\begin{tabular}{|c|c|c|c|c|c|}
\hline & \multirow{2}{*}{$\begin{array}{l}\text { Global } \\
\text { Mean }\end{array}$} & \multirow{2}{*}{$\begin{array}{l}\text { Std. } \\
\text { Dev. }\end{array}$} & \multicolumn{2}{|c|}{ Mean } & \multirow[t]{2}{*}{ t-test ${ }^{c}$} \\
\hline & & & Male & Female & \\
\hline${\text { Female } \text { client }^{b}}^{b}$ & 0.496 & 0.50 & & & \\
\hline 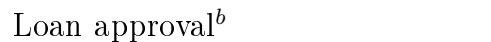 & 0.945 & 0.228 & 0.944 & 0.946 & -0.00213 \\
\hline Requested amount (X $100 \mathrm{BRL}^{a}$ ) & 13.92 & 12.42 & 15.26 & 12.54 & $2.722 * * *$ \\
\hline Loan size ( X $\left.100 \mathrm{BRL}^{a}\right)$ & 9.61 & 9.98 & 10.74 & 8.46 & $2.282 * * *$ \\
\hline
\end{tabular}

Applicant profile

\begin{tabular}{|c|c|c|c|c|c|}
\hline \\
\hline Age (in years) & 42.20 & 11.97 & 41.24 & 43.17 & $-1.925 * * *$ \\
\hline Married $^{b}$ & 0.47 & 0.50 & 0.52 & 0.43 & $0.0962 * * *$ \\
\hline At least one dependent ${ }^{b}$ & 0.52 & 0.50 & 0.53 & 0.51 & $0.0169 * *$ \\
\hline External income (X $\left.100 \mathrm{BRL}^{a}\right)$ & 2.13 & 3.76 & 2.11 & 2.16 & -0.04 \\
\hline \# former loans at Vivacred & 2.25 & 3.27 & 2.35 & 2.15 & $0.202 * * *$ \\
\hline \# former loans with delay (> 30 days) & 0.038 & 0.205 & 0.043 & 0.035 & $0.0077 * * *$ \\
\hline \# times as a guarantor & 0.74 & 2.11 & 0.89 & 0.6 & $0.282 * * *$ \\
\hline \multicolumn{6}{|c|}{ Business characteristics } \\
\hline Business profit (X $100 \mathrm{BRL}^{a}$ ) & 9.19 & 13.44 & 10.26 & 8.09 & $2.177 * * *$ \\
\hline Sector $($ trade $=1$, other $=0)$ & 0.53 & 0.50 & 0.49 & 0.56 & $-0.0760 * * *$ \\
\hline Official business ${ }^{b}$ & 0.06 & 0.23 & 0.07 & 0.05 & $0.0165 * * *$ \\
\hline \# employees & 0.63 & 2.20 & 0.72 & 0.54 & $0.175 * * *$ \\
\hline \multicolumn{6}{|c|}{ Credit characteristics } \\
\hline$\#$ of installments & 9.03 & 4.39 & 9.1 & 8.97 & $0.128 * *$ \\
\hline Investment purpose ${ }^{b}$ & 0.32 & 0.47 & 0.34 & 0.29 & $0.0518 * * *$ \\
\hline Loan repayment purpose ${ }^{b}$ & 0.09 & 0.29 & 0.08 & 0.1 & $-0.0171 * * *$ \\
\hline Guarantor's involvement $^{b}$ & 0.92 & 0.27 & 0.93 & 0.92 & $0.00756 * *$ \\
\hline Observations & & 33,850 & & & \\
\hline
\end{tabular}

${ }^{a}$ In 100 BRL corrected from the Rio de Janeiro state inflation index - IPC.

${ }^{b}$ Dummy variable: $\mathrm{Yes}=1$, No $=0$

${ }^{c}$ t-test for equal means between genders; ${ }^{* * *} \mathrm{p}<0.01,{ }^{* *} \mathrm{p}<0.05,{ }^{*} \mathrm{p}<0.1$

Vivacred claims no special focus on serving women. Table 3 shows that its clientele is balanced with $49.6 \%$ of loans attributed to women over the period 1997-2007. Figure 4 shows that the proportion of female applicants steadily 
Figure 4: Share of female applicants, and share of female credit officers

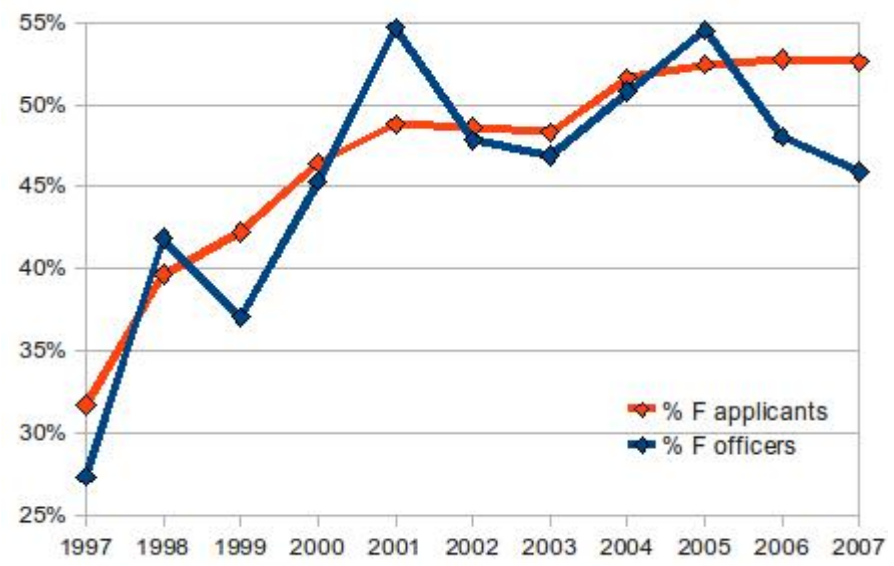

increased over the period ${ }^{18}$, rising from $32 \%$ to $53 \%$, which looks consistent with the decreasing average loan size as women typically ask for smaller credits. The share of female credit officers experienced a similar trend, in a more erratic way though.

Table 3 indicates that female applicants are on average two years older than male ones (45 versus 43 ), less likely married ( $43 \%$ versus $52 \%$ ), and less often with dependents (51\% versus 53\%). External income (i.e., earned by any household member, and not related to business activity) is similar (around BRL 210 a month) for male and female applicants.

Vivacred's male and female applicants differ not only in their personal situation, but also in their business characteristics. Indeed, table 3 shows that the female-owned businesses are typically smaller, in terms of both profit and staff size. The gendered business profit distribution is presented in figure 5. The female distribution exhibits a narrower shape toward zero, and consequently a smaller average profit.

The equal mean t-test in table 3 confirms that women ask for smaller loans than men (BRL 1,254 versus BRL 1,526) to be payed back in less installments. While $34 \%$ of the male loan applications are for capital investment (as opposed to liquidity needs), this proportion falls to $29 \%$ in female applications. The guarantor's and client's genders are unrelated. Men and women face similar approval rates (about 95\%), but women receive smaller loans, whether in absolute terms (BRL 846 versus BRL 1074), or proportionately to the requested amount $(73.7 \%$ versus $74.7 \%)$.

\footnotetext{
${ }^{18}$ A similar increase was observed for the Grameen Bank by Khandker, Khalily and Khan (1995).
} 
Figure 5: Business profit distribution by gender

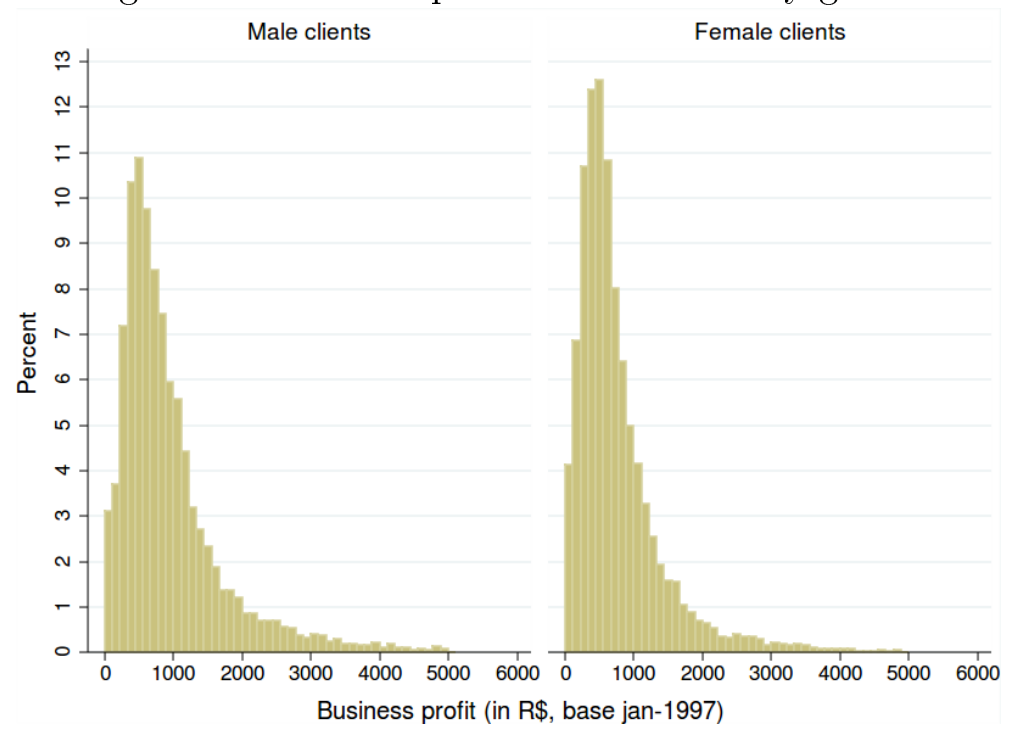

The next section will further investigate the loan approval probability and the loan size determination through regression analysis. It will check whether the findings from basic equal mean tests resist the inclusion of explanatory variables meant to proxy creditworthiness.

\section{Gender-specific Loan Approval and Loan Size}

Difference in denial rates is the cornerstone of the empirical literature on discrimination in the lending industry. Tests have been used for detecting discrimination based on race, gender, or ethnicity. ${ }^{19}$ Here, we focus on gender. Besides, given the special interest of MFIs in female borrowers, we draw no prior hypothesis regarding the potential bias, so allowing for detecting affirmative action (bias in favor of female applicants) as well as gender stereotyping (bias in favor of male applicants).

The usual testing methodology goes as follows. Discrimination against, say, group $F$ is suspected when the dummy variable associated to members of that group positively impacts loan denial, given that appropriate controls for creditworthiness are accounted for. Indeed, such an outcome means that,

\footnotetext{
${ }^{19}$ See Lacour-Little (1999) for a survey on models and methods on discrimination in mortgage lending, and Blanchard, Zhao and Yinger (2008) for a survey on discrimination in small-business lending.
} 
all other things being equal, applicants from group $F$ are facing more severe loan approval than others.

However, the decision to be taken by microcredit officers goes beyond loan approval or denial. In case of approval, loan size is also part of this decision. Indeed, unlike mortgage loans, productive loans can easily be sized by the lender. Therefore, the amount requested by each applicant is a relevant piece of information. Fortunately, our wealthy database includes all applicants' requests. These data make it possible to determine the extent to which gender-specific outcomes, if any, are attributable to gender-specific requests.

The use of the applicants' requested amount is not standard in the literature, likely because of data availability issues. However, introducing requested amount as an explanatory variable might bring multicollinearity. Therefore, our estimation strategy will depart from the classical approach. To our knowledge, this paper is the first one to use partial least square (PLS) estimation to test for discrimination in lending, as explained below.

Our theoretical model has shown that discriminated-against group members can suffer from excess credit rationing in two different ways: unfair loan denial, or unfair loan downsizing (with respect to same-creditworthiness non-discriminated-against group members). In that line, the empirical investigation starts with testing for gender differences in credit approval and loan size. The evolution of the gender gap along the project scale is left for the next section.

For the approval probability $\left(A_{i}=1\right.$ if applicant $i$ gets a loan, $A_{i}=0$ otherwise), we specify the following probit model:

$$
P\left(A_{i}=1\right)=\Phi\left(b_{F} F_{i}+b_{R} R A_{i}+\mathbf{b}_{\mathbf{X}}^{\prime} \mathbf{X}_{\mathbf{i}}\right)
$$

where $\Phi($.$) represents the normal probability distribution, F_{i}$ is the gender dummy $\left(F_{i}=1\right.$ if applicant $i$ is a woman, $F_{i}=0$ otherwise), $R A_{i}$ is the amount requested by applicant $i, \mathbf{X}_{\mathbf{i}}{ }^{20}$ is the vector summarizing the $J$ control variables for applicant $i$. The corresponding coefficients are $b_{F}, b_{R}$, and vector $\mathbf{b}_{\mathbf{X}}$, respectively.

The control variables are the ones typically used to assess creditworthiness. They include the borrower's personal information (age, marital status, external income, presence of dependents, guarantor's involvement and gender if involved), the business characteristics (past profits, sector, whether the business is official, number of employees), the credit characteristics (number

\footnotetext{
${ }^{20}$ Symbols in bold represent vectors.
} 
of installments and loan purpose), as well as the client's credit history with Vivacred (delays in previous loans, number of former loans as a client and as a guarantor). Year dummies are introduced in order to account for external economic factors.

A linear specification including the same independent variables is used for explaining the loan size:

$$
L S_{i}=c_{F} F_{i}+c_{R} R A_{i}+\mathbf{c}_{\mathbf{X}}^{\prime} \mathbf{X}_{\mathbf{i}}+\epsilon_{i}
$$

where $L S_{i}$ represents the loan size ${ }^{21}$ obtained by applicant $i$. The coefficients associated to the explanatory variables are denoted by $c_{F}, c_{R}$, and vector $\mathbf{c}_{\mathbf{X}}$, respectively.

In practice, loan size determination results from a sequential process: First, the applicant makes a loan request $R A_{i}$, then the MFI offers a loan of size $L S_{i}$. As shown in table 3 , the requested amount is gender-sensitive. Women request on average BRL 1, 254, while men request on average BRL 1, 526 ${ }^{22}$.

In order to properly address this issue, we implement a PLS estimation procedure (Wold et al., 1984; Tenenhaus, 1998; Helland, 1990) that rests upon a recursive specification. In the first step, we regress the requested amount on the gender dummy and the control variables, and determine the residual requested amount, $R R A_{i}$, that represents the amount requested by applicant $i$ cleaned from gender and controls effects:

$$
R A_{i}=a_{F} F_{i}+\mathbf{a}_{\mathbf{X}}^{\prime} \mathbf{X}_{\mathbf{i}}+R R A_{i}
$$

The gender dummy in equation (13) is indeed significant ${ }^{23}$. In the second step, we explain loan approval probability, respectively loan size, by the gender dummy, controls and residual requested amount. The approval probability equation ${ }^{24}$ becomes:

$$
P\left(A_{i}=1\right)=\Phi\left[\left(b_{F}+b_{R} a_{F}\right) F_{i}+\left(\mathbf{b}_{\mathbf{X}}^{\prime}+b_{R} \mathbf{a}_{\mathbf{X}}^{\prime}\right) \mathbf{X}_{\mathbf{i}}+b_{R} R R A_{i}\right]
$$

\footnotetext{
${ }^{21}$ Denied applications are captured as zero loans.

${ }^{22}$ We ignore why female applicants act in this way, and whether they expect a genderspecific treatment from the institution. This question will be raised in the conclusion.

${ }^{23} \mathrm{~A}$ female applicant's request lies on average BRL 107 below the request from a male applicant with similar characteristics. In the raw data (table 3), the difference amounted BRL 272.

${ }^{24}$ PLS is normally designed for linear regression, but we adapt it here to probit regression. By doing so, we might distort to some extent the marginal effects but the significance thresholds remain adequate, which is our main concern.
} 
Similarly, the loan size linear model writes:

$$
L S_{i}=\left(c_{F}+c_{R} a_{F}\right) F_{i}+\left(\mathbf{c}_{\mathbf{X}}^{\prime}+c_{R} \mathbf{a}_{\mathbf{X}}^{\prime}\right) \mathbf{X}_{\mathbf{i}}+c_{R} R R A_{i}+\epsilon_{i}
$$

By combining coefficients estimated from (13) and (14), respectively (13) and (15), we isolate the pure effects of requested amount on credit approval and loan size, respectively.

Table 4: Loan approval and loan size regressions

\begin{tabular}{lccc|ccc}
\hline & \multicolumn{3}{c|}{ Loan approval } & \multicolumn{3}{c}{ Loan size } \\
& \multicolumn{1}{c}{ Probit marginal effect at mean } & \multicolumn{3}{c}{ Linear regression } \\
& $(1)$ & $(2)$ & $(3)$ & $(4)$ & $(5)$ & $(6)$ \\
\hline Female applicant & 0.00254 & 0.00123 & 0.00254 & $-93.45^{* * *}$ & $-32.43^{* * *}$ & $-93.45^{* * *}$ \\
& $(0.00225)$ & $(0.00222)$ & $(0.00221)$ & $(8.665)$ & $(5.799)$ & $(5.791)$ \\
\hline Requested amount (RA) & & $-1.22 \mathrm{e}-05^{* * *}$ & & & $0.573^{* * *}$ \\
& & $(9.75 \mathrm{e}-07)$ & & $(0.00280)$ \\
Residual RA (RRA) & & & $-1.22 \mathrm{e}-05^{* * *}$ & & & $0.573^{* * *}$ \\
& & & $(9.75 \mathrm{e}-07)$ & & & $(0.00280)$ \\
\hline All controls & Yes & Yes & Yes & Yes & Yes & Yes \\
Observations & 33850 & 33850 & 33850 & 33850 & 33850 & 33850 \\
$R^{2}$ & & & & 0.390 & 0.728 & 0.728 \\
\hline
\end{tabular}

Standard errors in parentheses; ${ }^{* * *} \mathrm{p}<0.01,{ }^{* *} \mathrm{p}<0.05, * \mathrm{p}<0.1$. Monetary variables are measured in deflated BRL. Columns (1) and (2) estimate equation 11 with and without restriction $\left(b_{R}=0\right)$, column (3) estimates equation 14, columns (4) and (5) estimate equation 12 with and without restriction $\left(c_{R}=0\right)$, column (6) estimates equation 15 .

Table 4 presents the marginal effects at the mean for the probit regression and the estimated coefficients for the loan size regression. In specifications $(1)$ and $(4)$, the requested amount is ignored $\left(b_{R}=0\right)$. Specifications $(2)$ and (5) include the requested amount, while specifications (3) and (6) include the residual requested amount. In (1) and (2), the coefficients are estimated from the standard probit (eq.11). In (3), the "PLS-like" probit model includes the residual requested amount (eq. 14). In (4) and (5), the coefficients are estimated by OLS (eq. 12), in (6) by PLS (eq. 15).

Whatever the specification, no gender difference is observed in the credit approval probability. This result confirms the similarity in approval rate between men and women uncovered in descriptive statistics (table 3).

The impact of gender on loan size sharply contrasts with the gender neutrality observed on approval rate. Indeed, in the right-hand side of table 4 all specifications exhibit significantly negative coefficients for the gender dummy, meaning that, all other things being equal (including the requested amount), women get smaller loans than men. 
Moreover, the comparison of (4) and (5) highlights the difference in coefficient magnitudes. In specification (4), the female dummy coefficient is equal to $(-93.45)$, while in $(5)$ it reaches $(-32.43)$. Thus, women do indeed get smaller loans, but largely because, under similar circumstances, they ask for smaller loans than men. Specification (6) explicitly takes into account the requested amount cleaned from its female component. While the gender dummy coefficient estimates have identical values in (4) and (6), specification (6) offers more precision (smaller standard error) and more explanatory power (larger $R^{2}$ ).

To sum up, the results show that credit approval is not affected by the applicant's gender, but loan size determination is detrimental to female borrowers. As a consequence, the estimations clearly exclude the situation referred to as "case 1" (loan denial to a given group) in our theoretical model. However, the specifications used in this section fall short in detecting a gender gap varying with the project scale, like in "case 2" (glass ceiling effect). Better suited specifications are proposed in the next section.

\section{Is there a Glass Ceiling in Loan Size ?}

The theory in section 2 has demonstrated that biased credit officers exhibit heterogeneous impact, leading to the possibility for a glass ceiling effect. By "glass ceiling effect", we mean that women with large expected revenue end up with more cut down loans than those with small expected revenues. In order to assess this theoretical prediction, we slighly modify the loan size regression and allow the gender dummy to interact with the project scale.

In specification (15), loan size linearly depends on the requested amount with a common slope for men and women. The interaction between gender and project scale may take various forms. Therefore, we consider two alternative specifications for this interaction in the loan size regression: a gender-specific slope and a gender-specific quadratic term, both with respect to the residual requested amount (PLS estimation).$^{25}$

The model with a gender-specific slope is :

$$
L S_{i}=c_{F} F_{i}+c_{R} R R A_{i}+c_{R F} R R A_{i} F_{i}+\mathbf{c}_{\mathbf{X}}^{\prime} \mathbf{X}_{\mathbf{i}}+\epsilon_{i}
$$

where $L S_{i}$ is the loan size, $F_{i}$ is the gender dummy $\left(F_{i}=1\right.$ if applicant $i$ is a woman, $F_{i}=0$ otherwise), $R R A_{i}$ is the residual requested amount, and

\footnotetext{
${ }^{25}$ OLS regressions produce similar results (not reported).
} 
vector $\mathbf{X}_{\mathbf{i}}$ summarizes the controls. The possibility for a glass-ceiling effect is provided by parameter $c_{R F}$.

Importantly, the interaction variable, $R R A_{i} F_{i}$, is added to the specification already including the gender dummy $F_{i}$, allowing to split the gender impact in two parts. On the one hand, coefficient $c_{F}$ applies to all women, irrespectively of their project size. On the other hand, $c_{R F}$ depends on the project scale. Only a significantly negative $c_{R F}$ would bear witness to a glass ceiling in loan size.

The second specification includes linear and quadratic residual requested amount, as well as a gender-specific quadratic term allowing for a differential concavity effect:

$$
L S_{i}=c_{F} F_{i}+c_{R} R R A_{i}+c_{Q}\left(R R A_{i}\right)^{2}+c_{Q F} F_{i}\left(R R A_{i}\right)^{2}+\mathbf{c}_{\mathbf{X}}^{\prime} \mathbf{X}_{\mathbf{i}}+\epsilon_{i}
$$

Under specification (17), a significant negative value for $c_{Q F}$ would capture the glass-ceiling effect. Moreover, such quadratic effect would be stronger than in equation (16) because it would reflect a gender gap that not only increases, but also accelerates with the project scale.

Table 5: Estimation of two specifications for glass ceiling detection

\begin{tabular}{lcc}
\hline & \multicolumn{2}{c}{ Loan size } \\
& $(1)$ & $(2)$ \\
\hline Female client (F) & $-84.57^{* * *}$ & $-49.06^{* * *}$ \\
& $(5.816)$ & $(5.977)$ \\
RRA & $0.618^{* * *}$ & $0.556^{* * *}$ \\
& $(0.00357)$ & $(0.00336)$ \\
$\mathrm{RRA}^{*} \mathrm{~F}$ & $-0.119^{* * *}$ & \\
& $(0.00591)$ & \\
$\mathrm{RRA}^{2}$ & & $1.42 \mathrm{e}-05^{* * *}$ \\
& & $(6.93 \mathrm{e}-07)$ \\
$\mathrm{RRA}^{2} * \mathrm{~F}$ & & $-3.50 \mathrm{e}-05^{* * *}$ \\
& & $(1.61 \mathrm{e}-06)$ \\
\hline All controls & Yes \\
$\mathrm{Observations}^{2}$ & 33850 & 33850 \\
$\mathrm{R}^{2}$ & 0.727 & 0.729 \\
\hline \multicolumn{2}{l}{ Standard errors in parentheses; $* * * \mathrm{p}<0.01$} \\
\multicolumn{2}{c}{ Financial values in deflated $\mathrm{BRL}(\mathrm{R} \$)$}
\end{tabular}

Table 5 gives the estimation results for both specifications: equation (16) in column (1), and equation (17) in column (2). The glass ceiling theoretical prediction is confirmed in both cases. Indeed, column (1) exhibits a significantly negative coefficient for the size-dependent interaction term. The gender gap in loan size is thus increasing with the project scale. 
Figure 6: Linear and quadratic adjustments for loan size

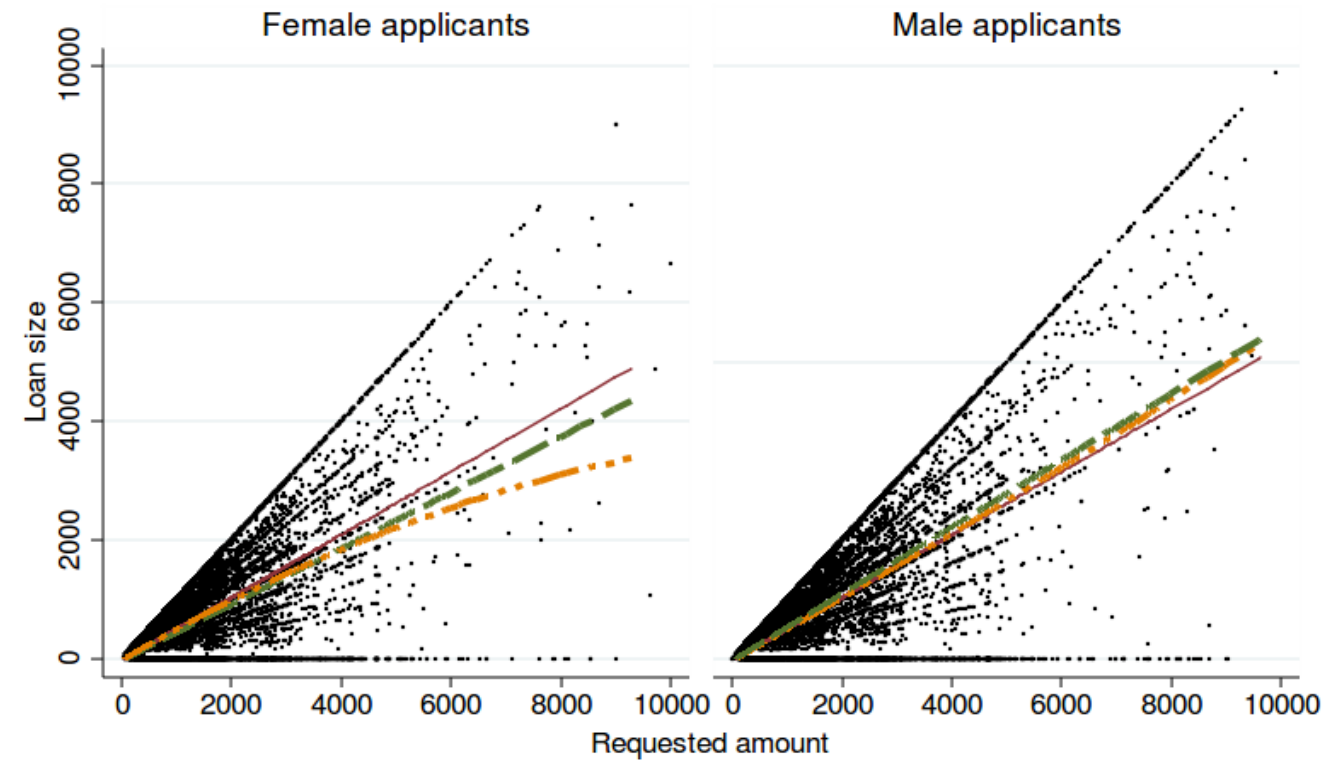

Observations common linear term gender-specific linear term gender-specific quadratic term

In the same vein, column (2) shows that the quadratic size-dependent gender effect is significantly negative. Compared to men with same characteristics, women with larger projects are more restricted. As the control variables coefficients are similar to those found in table 4, we do not report them. Specifications (1) and (2) in table 5 have about the same explanatory power $\left(R^{2}=0.73\right)$.

Figure 6 illustrates the regression results by gender. Each graph represents the gendered loan size as a function of the requested amount. The dashed lines, respectively curves, are the linear, respectively quadratic, trends of the gender-specific slope regression. The thin continuous line is the common linear trend (from equation 17) provided as a benchmark. Figure 6 shows that both specifications offer reasonable pictures of the scatter plot.

Figure 6 also illustrates that the quadratic specification corresponds to a much stronger glass ceiling effect. For example, for a BRL 10,000 request (which is very high according to Vivacred's standards), the gender-specific linear specification predicts an average loan size difference of BRL 1,275 between male and female clients whereas the quadratic specification predicts 
a BRL 3,550 difference.

The glass ceiling effect found in Vivacred's data likely originate from gender stereotyping. Such an interpretation is compatible with Buttner and Rosen (1988)'s findings on gender stereotyping involved in US bank loan officers' evaluation of successful entrepreneurs. Indeed, those authors confirm "the hypothesis that characteristics attributed to successful entrepreneurs were more commonly ascribed to men than to women. On the dimensions of leadership, autonomy, risk taking, readiness for change, endurance, lack of emotionalism and low need for support, bank loan officers rated women as significantly less like successful entrepreneurs compared to men." (p. 249)

Sexton and Bowman-Upton (1990) show that gender-related managerial differences do exist, notably in risk aversion, but are largely overweighted as the basis for gender stereotyping. More broadly, the gender differences in entrepreneurial characteristics and performances in developed countries are debated in the literature and the evidence of discrimination remains controversial $^{26}$. Nevertheless, even when gender discrimination is acknowledged, it seems to have a strikingly little impact on the chances of success of femaleowned small businesses (Fischer, Reuber and Dyke, 1993), perhaps because women make a better use of their social capital (Carter et al., 2003). Still, transposing those results to poor micro-entrepreneurs in developing countries is far from obvious.

In equations (16) and (17), the residual requested amount stands as a proxy for the size of the project, corresponding to parameter $(1-\pi(x))$ in the theoretical model. In order to check the robustness of our results with respect to the use of such proxy, we reproduce the estimations using this time the household external income as an alternative proxy for parameter $(1-\pi(x))$. The results are in table 6 .

Compared to columns (1) and (4) in table 4, column (1) in table 6 shows that, under linear specification, gender-specific external income and genderspecific residual requested amount drive similar effects.

However, the second specification (column (2) in table 6) reveals that the global quadratic impact (coefficient of $E I^{2}$ ) is negative, meaning that the impact of external income on loan size is proportionately lower for higher income borrowers, whatever their gender. Still, this impact is much higher for females since the estimated coefficient of the interaction term $\left(E I^{2} * F\right)$ is not only significant, but also about three times higher than the global effect.

\footnotetext{
${ }^{26}$ For instance, Haines, Orser and Riding (1999) use Canadian data and claim that "borrower attributes and terms of lending do not vary by gender of borrower" (p.291).
} 
Table 6: Loan size estimation: Gender interacting with external income

\begin{tabular}{|c|c|c|}
\hline & \multicolumn{2}{|c|}{ Loan size } \\
\hline & (1) & $(2)$ \\
\hline Female client $(\mathrm{F})$ & $\begin{array}{c}-59.59^{* * *} \\
(6.715)\end{array}$ & $\begin{array}{c}-78.10^{* * *} \\
(5.906)\end{array}$ \\
\hline External income (EI) & $\begin{array}{c}0.342^{* * *} \\
(0.0102)\end{array}$ & $\begin{array}{c}0.369^{* * *} \\
(0.0106)\end{array}$ \\
\hline $\mathrm{EI} * \mathrm{~F}$ & $\begin{array}{c}-0.114^{* * *} \\
(0.0153)\end{array}$ & \\
\hline $\mathrm{EI}^{2}$ & & $\begin{array}{c}-1.26 \mathrm{e}-05^{* * *} \\
(1.77 \mathrm{e}-06)\end{array}$ \\
\hline $\mathrm{EI}^{2} * \mathrm{~F}$ & & $\begin{array}{c}-4.11 \mathrm{e}-05^{* * *} \\
(5.17 \mathrm{e}-06)\end{array}$ \\
\hline All controls & Yes & Yes \\
\hline Observations & 33850 & 33850 \\
\hline $\mathrm{R}^{2}$ & 0.724 & 0.725 \\
\hline
\end{tabular}

Additionally, external income can be viewed as a partial collateral. Following this interpretation, table 6 provides an evidence that, all things being equal, a female borrower with a larger project needs more collateral than a man in a comparable situation. This could reflect the lender's knowledge that intrahousehold income allocation is favorable to men, making external revenue less relevant as a collateral for female borrowers.

At this point, we have confirmed the theoretical prediction that the gender gap in loan size is more severe for larger loans. However, the responsibilities for disparate treatment within the MFI remain unclear. In particular, one could wonder whether the credit officer's gender matters. This is the topic of the next section.

\section{Impact of the Credit Officer's Gender}

In this section, we study whether the credit officer's gender interferes with the disparate treatment endured by female clients. Such interference could take place because female credit officers adopt a different screening strategy than their male colleagues, and/or because some kind of gender affinity makes credit officers favor or better assess clients of the same gender.

Women are typically more risk averse than men in financial decision making (Olsen and Cox, 2001; Barber and Odean, 2001; Jianakopolos and Bernasek, 1998). Moreover, the beneficial impact of gender diversity on firm gover- 
nance and firm value has been largely acknowledged in microfinance and elsewhere. ${ }^{27}$ Applied to credit officers, this argument could imply that costefficient female officers mitigate economically unsound biases, whether against women or any other group. For instance, Guérin, Mersland and D'Espallier (2009) show that female officers increase the odds of serving female clients.

Gender affinity, as a special case of cultural affinity (Bostic, 2003), may act in two opposite directions: as an inefficient intra-group favoritism ${ }^{28}$ (Ahmed, 2007; Szafarz, 2008), or as an efficient tool for creditworthiness assessment (Carter et al., 2007; Ferguson and Peters, 1997). Therefore, the effect of gender affinity, if any, is not clear-cut.

This section examines how female applicants are treated by female and male credit officers, separately. For that purpose, we first compare the loan portfolios of female and male officers. Then, we run the loan size regressions like in section 5, but splitting the full sample in two by credit officer's gender.

Table 7 gives the contingency table associating the applicant's gender to the credit officer's gender. Each combination roughly concerns one quarter of the loans. Nevertheless, the $\chi^{2}$ independence test indicates that officers deal significantly more with clients of the same gender ${ }^{29}$.

Table 7: Percentages of loan requests by applicant's and officer's gender

\begin{tabular}{lccc}
\hline$\%$ & Female applicant & Male applicant & Total (applicants) \\
\hline Female credit officer & 23.46 & 24.66 & 48.12 \\
Male credit officer & 26.95 & 24.92 & 51.88 \\
Total (credit officers) & 50.41 & 49.59 & 100.00 \\
\hline
\end{tabular}

Table 8 compares the characteristics of female and male loan applicants dealing with female and male credit officers, respectively. Confirming the obser-

\footnotetext{
${ }^{27}$ See, e.g., Erhardt, Werbel and Shrader (2003) and Carter, Simkins and Simpson (2003) on the positive impact of diversity (ethnic and gender differences) on boards. Regarding microfinance specifically, Hartarska (2005) finds evidence that in Eastern Europe and Central Asian, MFIs with higher proportion of women on their board reach poorer borrowers. Caudill, Gropper and Hartarska (2009) show that US Community Development Funds with more gender diversity on the board are more cost-efficient.

${ }^{28}$ Biggs, Raturi and Srivastava (2002) illustrate the occurrence of such affinity in informal finance in Kenya.

${ }^{29}$ Pearson $\chi^{2}(1)=33.6798$ and $\mathrm{P}$-value $=0.000$. This effect is surprising given that, in Vivacred, each credit officer has a specific geographic area to serve. Nonetheless, it could be the case that female officers are allocated to areas exhibiting a higher concentration of female businesses. To provide a full picture of the situation, we have tested for the difference of male and female officers' in each characteristic (see table 10 in Appendix A). While several differences are significant, female credit officers do not seem to face systematically worse loan portfolios.
} 
vation from table 7 , it appears that female credit officers meet slightly more female applicants than male credit officers (51\% against 48\%). Although applicants request the same average amount (BRL 1392) to credit officers of both genders, female officers systematically propose smaller loans (BRL 999) than male ones (BRL 1065) to the committee. Accordingly, clients attended by female credit officers get smaller loans (BRL 977 against BRL 1049) when approved.

For the remaining, table 8 indicates that the differences in characteristics between male and female applicants, split according to their credit officer's gender, are similar to those observed in table 3 for the full sample.

Table 8: Descriptive statistics by credit officers' and applicants' genders

\begin{tabular}{|c|c|c|c|c|c|c|}
\hline \multirow[b]{2}{*}{ Client } & \multicolumn{3}{|c|}{ Female credit officer } & \multicolumn{3}{|c|}{ Male credit officer } \\
\hline & Male & Female & t-test ${ }^{c}$ & Male & Female & t-test ${ }^{c}$ \\
\hline Female client $^{a}$ & & 0.512 & & & 0.480 & \\
\hline Loan approval $^{a}$ & 0.927 & 0.928 & -0.0007 & 0.945 & 0.948 & -0.0030 \\
\hline Requested Amount (BRL) & 1554.4 & 1257.6 & $296.8 * * *$ & 1501.9 & 1250.6 & $251.3 * * *$ \\
\hline Proposed amount (BRL) & 1134.6 & 880.5 & $254.1 * * *$ & 1171.5 & 950.7 & $220.7 * * *$ \\
\hline Loan size (BRL) & 1042.8 & 802.4 & $240.4 * * *$ & 1101.8 & 889.5 & $212.3 * * *$ \\
\hline \multicolumn{7}{|c|}{ Applicant profile } \\
\hline Married $^{a}$ & 0.528 & 0.434 & $0.0943 * * *$ & 0.514 & 0.415 & $0.099 * * *$ \\
\hline At least one dependent ${ }^{a}$ & 0.518 & 0.502 & $0.0163 *$ & 0.530 & 0.513 & $0.0167 *$ \\
\hline Age (in years) & 41.5 & 43.6 & $-2.130 * * *$ & 41.0 & 42.7 & $-1.689 * * *$ \\
\hline External income (BRL) & 185.7 & 187.0 & -1.34 & 233.5 & 243.8 & -10.31 \\
\hline \# former loans at Vivacred & 2.205 & 1.996 & $0.209 * * *$ & 2.481 & 2.303 & $0.177 * * *$ \\
\hline \# former loans with delay & 0.763 & 0.478 & $0.285 * * *$ & 0.991 & 0.725 & $0.266 * * *$ \\
\hline \# times as a guarantor & 0.034 & 0.029 & 0.005 & 0.043 & 0.033 & $0.0097 * *$ \\
\hline \multicolumn{7}{|c|}{ Credit characteristics } \\
\hline \# of installments & 9.007 & 8.973 & 0.033 & 9.173 & 8.962 & $0.211 * *$ \\
\hline Investment purpose $^{a}$ & 0.348 & 0.289 & $0.0590 * * *$ & 0.336 & 0.290 & $0.0455 * * *$ \\
\hline Loan repayment purpose ${ }^{a}$ & 0.088 & 0.107 & $-0.0191 * * *$ & 0.081 & 0.095 & $-0.0146 * * *$ \\
\hline Guarantor's involvement $^{a}$ & 0.941 & 0.935 & 0.006 & 0.917 & 0.906 & $0.0109 *$ \\
\hline \multicolumn{7}{|c|}{ Business characteristics } \\
\hline Business profit (BRL) & 1089.5 & 812.1 & $277.4 * * *$ & 971.8 & 805.5 & $166.3 * * *$ \\
\hline Sector $($ trade $=1)$ & 0.507 & 0.584 & $-0.0770 * * *$ & 0.471 & 0.543 & $-0.0725 * * *$ \\
\hline Official business $^{a}$ & 0.063 & 0.052 & $0.0106 * *$ & 0.070 & 0.048 & $0.0217 * * *$ \\
\hline \# employees & 0.766 & 0.604 & $0.162 * * *$ & 0.673 & 0.480 & $0.193 * * *$ \\
\hline
\end{tabular}

In order to check whether the credit officer's gender matters for loan size, we run the same regressions as in table 5 but for applications treated by female and male officers, separately. The results are reported in table 9. For 
each explanatory variable, the Chow test indicates whether the coefficients estimated on the two subsamples are significantly different.

Table 9: Separate loan size regressions for female and male credit officers

\begin{tabular}{|c|c|c|c|c|c|c|}
\hline Subsample (credit officer) & Female & Male & Chow Test & Female & Male & Chow Test \\
\hline Loan size & $(1)$ & $(2)$ & $(3)$ & $(4)$ & $(5)$ & (6) \\
\hline $\mathrm{F}$ & $\begin{array}{c}-104.1^{* * *} \\
(8.594)\end{array}$ & $\begin{array}{c}-63.92^{* * *} \\
(7.742)\end{array}$ & $\begin{array}{c}-40.18^{* * *} \\
(11.54)\end{array}$ & $\begin{array}{c}-44.93^{* * *} \\
(8.775)\end{array}$ & $\begin{array}{c}-45.06^{* * *} \\
(7.960)\end{array}$ & $\begin{array}{c}0.129 \\
(11.82)\end{array}$ \\
\hline RRA & $\begin{array}{c}0.576^{* * *} \\
(0.00558)\end{array}$ & $\begin{array}{c}0.642^{* * *} \\
(0.00457)\end{array}$ & $\begin{array}{c}-0.0661^{* * *} \\
(0.00717)\end{array}$ & $\begin{array}{c}0.510^{* * *} \\
(0.00483)\end{array}$ & $\begin{array}{c}0.579^{* * *} \\
(0.00473)\end{array}$ & $\begin{array}{c}-0.0692^{* * *} \\
(0.00676)\end{array}$ \\
\hline $\mathrm{RRA} * \mathrm{~F}$ & $\begin{array}{c}-0.137^{* * *} \\
(0.00885)\end{array}$ & $\begin{array}{c}-0.0973^{* * *} \\
(0.00784)\end{array}$ & $\begin{array}{c}-0.0402^{* * *} \\
(0.0118)\end{array}$ & & & \\
\hline $\mathrm{RRA}^{2}$ & & & & $\begin{array}{c}1.83 \mathrm{e}-05^{* * *} \\
(1.02 \mathrm{e}-06)\end{array}$ & $\begin{array}{c}1.27 \mathrm{e}-05^{* * *} \\
(9.45 \mathrm{e}-07)\end{array}$ & $\begin{array}{c}5.67 \mathrm{e}-06^{* * *} \\
(1.39 \mathrm{e}-06)\end{array}$ \\
\hline $\mathrm{RRA}^{2} * \mathrm{~F}$ & & & & $\begin{array}{c}-6.13 \mathrm{e}-05^{* * *} \\
(2.48 \mathrm{e}-06)\end{array}$ & $\begin{array}{c}-1.58 \mathrm{e}-05^{* * *} \\
(2.06 \mathrm{e}-06)\end{array}$ & $\begin{array}{c}-4.55 \mathrm{e}-05^{* * *} \\
(3.21 \mathrm{e}-06) \\
\end{array}$ \\
\hline$\#$ of former loans & $\begin{array}{c}50.35^{* * *} \\
(1.529)\end{array}$ & $\begin{array}{c}48.11^{* * * *} \\
(1.324)\end{array}$ & $\begin{array}{c}2.245 \\
(2.015)\end{array}$ & $\begin{array}{c}49.85^{* * *} \\
(1.508)\end{array}$ & $\begin{array}{c}47.35^{* * *} \\
(1.326)\end{array}$ & $\begin{array}{c}2.508 \\
(2.003)\end{array}$ \\
\hline \# of times as a guarantor & $\begin{array}{c}16.47^{* * *} \\
(2.335)\end{array}$ & $\begin{array}{c}8.858^{* * *} \\
(1.798)\end{array}$ & $\begin{array}{c}7.614^{* * *} \\
(2.926)\end{array}$ & $\begin{array}{c}15.35^{* * *} \\
(2.305)\end{array}$ & $\begin{array}{c}7.614^{* * *} \\
(1.798)\end{array}$ & $\begin{array}{c}7.737^{* * *} \\
(2.906)\end{array}$ \\
\hline \# of past delays & $\begin{array}{c}-292.7^{* * *} \\
(22.86)\end{array}$ & $\begin{array}{c}-299.5^{* * *} \\
(18.75)\end{array}$ & $\begin{array}{c}6.838 \\
(29.41)\end{array}$ & $\begin{array}{c}-286.1^{* * *} \\
(22.54)\end{array}$ & $\begin{array}{c}-296.5^{* * *} \\
(18.73)\end{array}$ & $\begin{array}{c}10.38 \\
(29.18)\end{array}$ \\
\hline Married & $\begin{array}{c}53.53^{* * *} \\
(8.897)\end{array}$ & $\begin{array}{c}42.55^{* * *} \\
(8.044)\end{array}$ & $\begin{array}{c}10.98 \\
(11.97)\end{array}$ & $\begin{array}{c}53.03^{* * *} \\
(8.776)\end{array}$ & $\begin{array}{c}42.80^{* * *} \\
(8.036)\end{array}$ & $\begin{array}{c}10.24 \\
(11.88)\end{array}$ \\
\hline At least one dependent & $\begin{array}{c}28.23^{* * *} \\
(8.836)\end{array}$ & $\begin{array}{c}11.09 \\
(8.257)\end{array}$ & $\begin{array}{c}17.13 \\
(12.08)\end{array}$ & $\begin{array}{c}25.47^{* * *} \\
(8.713)\end{array}$ & $\begin{array}{c}8.490 \\
(8.249)\end{array}$ & $\begin{array}{c}16.98 \\
(11.99)\end{array}$ \\
\hline Age (in years) & $\begin{array}{c}-1.020^{* * *} \\
(0.364)\end{array}$ & $\begin{array}{c}-3.090^{* * *} \\
(0.331)\end{array}$ & $\begin{array}{c}2.070^{* * *} \\
(0.491)\end{array}$ & $\begin{array}{c}-1.002^{* * *} \\
(0.359)\end{array}$ & $\begin{array}{c}-3.173^{* * *} \\
(0.331)\end{array}$ & $\begin{array}{c}2.171^{* * *} \\
(0.487)\end{array}$ \\
\hline Guarantor involved & $\begin{array}{c}278.0^{* * *} \\
(18.02)\end{array}$ & $\begin{array}{c}280.7^{* * *} \\
(13.89)\end{array}$ & $\begin{array}{l}-2.743 \\
(22.59)\end{array}$ & $\begin{array}{c}277.9^{* * *} \\
(17.76)\end{array}$ & $\begin{array}{c}283.5^{* * *} \\
(13.87)\end{array}$ & $\begin{array}{l}-5.621 \\
(22.41)\end{array}$ \\
\hline \# of installments & $\begin{array}{c}53.36^{* * *} \\
(1.107)\end{array}$ & $\begin{array}{c}61.99^{* * *} \\
(0.842)\end{array}$ & $\begin{array}{c}-8.635^{* * *} \\
(1.381)\end{array}$ & $\begin{array}{c}54.16^{* * *} \\
(1.099)\end{array}$ & $\begin{array}{c}61.42^{* * *} \\
(0.847)\end{array}$ & $\begin{array}{c}-7.267^{* * *} \\
(1.379)\end{array}$ \\
\hline Investment purpose & $\begin{array}{c}146.2^{* * *} \\
(9.549)\end{array}$ & $\begin{array}{c}173.5^{* * *} \\
(8.750)\end{array}$ & $\begin{array}{c}-27.28^{* *} \\
(12.93)\end{array}$ & $\begin{array}{c}146.3^{* * *} \\
(9.417)\end{array}$ & $\begin{array}{c}171.4^{* * * *} \\
(8.742)\end{array}$ & $\begin{array}{c}-25.13^{*} \\
(12.83)\end{array}$ \\
\hline Loan repayment & $\begin{array}{c}64.32^{* * *} \\
(15.19)\end{array}$ & $\begin{array}{c}101.6^{* * *} \\
(14.22)\end{array}$ & $\begin{array}{c}-37.27^{*} \\
(20.78)\end{array}$ & $\begin{array}{c}59.42^{* * *} \\
(14.99)\end{array}$ & $\begin{array}{c}100.4^{* * *} \\
(14.20)\end{array}$ & $\begin{array}{c}-40.93^{* *} \\
(20.62)\end{array}$ \\
\hline External income & $\begin{array}{c}0.257^{* * *} \\
(0.0121)\end{array}$ & $\begin{array}{l}0.315^{* * *} \\
(0.00999)\end{array}$ & $\begin{array}{c}-0.0579 * * * \\
(0.0156)\end{array}$ & $\begin{array}{c}0.267^{* * *} \\
(0.0119)\end{array}$ & $\begin{array}{l}0.323^{* * *} \\
(0.00999)\end{array}$ & $\begin{array}{c}-0.0554^{* * *} \\
(0.0155)\end{array}$ \\
\hline Business profit & $\begin{array}{l}0.182^{* * *} \\
(0.00295)\end{array}$ & $\begin{array}{c}0.237^{* * *} \\
(0.00359)\end{array}$ & $\begin{array}{c}-0.0548^{* * *} \\
(0.00468)\end{array}$ & $\begin{array}{l}0.209^{* * *} \\
(0.00310)\end{array}$ & $\begin{array}{l}0.255^{* * *} \\
(0.00390)\end{array}$ & $\begin{array}{c}-0.0462^{* * *} \\
(0.00501)\end{array}$ \\
\hline Trade (sector) & $\begin{array}{l}-9.318 \\
(8.909)\end{array}$ & $\begin{array}{c}-52.60^{* * *} \\
(8.065)\end{array}$ & $\begin{array}{c}43.28^{* * *} \\
(11.99)\end{array}$ & $\begin{array}{c}-16.20^{*} \\
(8.791)\end{array}$ & $\begin{array}{c}-52.48^{* * *} \\
(8.060)\end{array}$ & $\begin{array}{c}36.28^{* * *} \\
(11.90)\end{array}$ \\
\hline Official business & $\begin{array}{c}622.6^{* * *} \\
(19.40)\end{array}$ & $\begin{array}{c}777.0^{* * *} \\
(17.41)\end{array}$ & $\begin{array}{c}-154.4^{* * *} \\
(26.00)\end{array}$ & $\begin{array}{c}608.3^{* * *} \\
(19.20)\end{array}$ & $\begin{array}{c}753.8^{* * *} \\
(17.54)\end{array}$ & $\begin{array}{c}-145.5^{* * *} \\
(25.96)\end{array}$ \\
\hline \# employees & $\begin{array}{c}55.36^{* * *} \\
(2.309)\end{array}$ & $\begin{array}{c}39.74 * * * \\
(1.676)\end{array}$ & $\begin{array}{c}15.61^{* * *} \\
(2.827)\end{array}$ & $\begin{array}{c}47.08^{* * *} \\
(2.346)\end{array}$ & $\begin{array}{c}29.91^{* * *} \\
(1.796)\end{array}$ & $\begin{array}{c}17.17^{* * *} \\
(2.937)\end{array}$ \\
\hline Constant & $\begin{array}{c}24.84 \\
(65.41) \\
\end{array}$ & $\begin{array}{c}215.8^{* * *} \\
(44.94) \\
\end{array}$ & $\begin{array}{c}-190.9^{* *} \\
(78.53) \\
\end{array}$ & $\begin{array}{l}-31.50 \\
(64.52) \\
\end{array}$ & $\begin{array}{c}194.2^{* * *} \\
(44.93) \\
\end{array}$ & $\begin{array}{c}-225.7^{* * *} \\
(77.98) \\
\end{array}$ \\
\hline Observations & 16263 & 17587 & & 16263 & 17587 & \\
\hline $\mathrm{R}^{2}$ & 0.667 & 0.777 & & 0.676 & 0.778 & \\
\hline
\end{tabular}

Leaving aside the applicant's gender impact (discussed below), it appears from table 9 that female and male credit officers screen their clients differently. Indeed, although the coefficients of the regressions pertaining to 
female and male credit officers exhibit same sign (except for the constant term), numerous significant differences emerge.

Notably, the constant is significant only in the regressions concerning male credit officers (columns (2) and (5)), pinpointing that male and female credit officers do not use the same scales in judging their clients' projects. Male officers start from a positive benchmark (even for female clients, since the female dummy coefficient is smaller than the constant term) while female officers start from zero, or even below zero for their female applicants.

Compared to their male colleagues, female officers downweight characteristics testifying for loan securing: external income, business profit, and official business. This could be a consequence of a higher risk aversion, leading to granting smaller loans.

Whatever the specification (linear or quadratic), the regressions concerning both the male and female credit officers do exhibit the glass ceiling stigma. However, the differences in scale and in control weighting make the glass ceiling intensities hardly comparable. Further investigation would be needed to compare the gender gap resulting from treatment by female and male officers ${ }^{30}$. This gap varies with the client's profile in many dimensions. For instance, a female borrower from the trade sector who formerly acted as a guarantor could receive a larger loan from a female credit officer despite the fact that such an officer provides smaller loans on average.

All in all, the ways female and male credit officers evaluate their clients' creditworthiness are strikingly different but the glass ceiling effect is present whatever the officer's gender, and robust to model specification ${ }^{31}$.

\section{Conclusion}

The theoretical model in section 2 has shown that bias in loan granting with fixed interest rate implies that more profitable applicants from the group that suffers from discrimination end up being the most credit-constrained.

\footnotetext{
${ }^{30}$ In order to capture gender-gaps associated to every credit officer working at Vivacred, we included interactions between the 40 credit officers' dummies and the clients' gender dummy. Among the 40 credit officers, 26 (13 men, and 13 women) exhibit a non significant coefficient (at the $5 \%$ level), 11 ( 5 men, and 6 women) exhibit a biais against female clients, and 3 ( 1 man, and 2 women) exhibit a biais against male clients.

${ }^{31} \mathrm{~A}$ third specification based on sample splitting with respect to the project scale is provided in Appendix B. It confirms that the presence of a glass ceiling effect in male and female officers' loan size determination. Gender stereotypes are shared by both male and female officers.
} 
The empirical evidence based on highly disaggregated data exhibits mixed results: Loan approval rate is fairly distributed across genders, but loan size is biased in favor of male clients. Moreover, the theoretical prediction that women with larger projects receive proportionally smaller loans is confirmed. This glass ceiling effect is robust to econometric specification.

Importantly, this paper raises serious doubts about two assumptions commonly made in empirical microfinance papers. First, the gender dummy is not an appropriate proxy for poverty level for at least two reasons: 1) it mixes poverty and potential bias, and 2) women tend to ask for smaller loans than men with similar characteristics. Second, average loan size is an unsatisfactory assessment tool for the MFIs' social mission. On top of being abusively penalizing for cross-subsidization (Armendariz and Szafarz, 2009), average loan size might indeed be artificially reduced by biased treatment of some clientele segments. Therefore, we favor the use of outreach, preferably weighted by some gender-insensitive indicator of the clients' poverty level.

This paper also shows that the glass ceiling effect is present whatever the credit officer's gender. Therefore, our findings do not support the "gender affinity" hypothesis in the spirit of the "cultural affinity" theory tested for in mortgage lending (Hunter and Walker, 1996; Bostic, 2003).

Understanding why female and male officers adopt diverging screening methodologies goes beyond the scope of this paper, but psychological factors linked to business risk perception are likely involved (Borghans et al., 2009). Such factors could also explain why female applicants request smaller loans than their male counterparts with similar characteristics. Alternatively, female borrowers could refrain from requesting loans that would put at risk their financial situation within household. Such a rationale would be in line with the findings that microcredit increases the women's financial vulnerability (Garikipati, 2008; Guérin et al., 2009).

Gender stereotyping has been observed in a wide variety of situations in developed countries, including small-business lending. It is thus no surprise that it also shows off in Brazil. Therefore, the fact that our results capture no gender gap in loan approval rate is remarkable, especially given persistent inequalities reported in denial rates in the US banking sector (Weller, 2009). Nevertheless, further studies are needed to check the robustness of our findings on other MFIs, in particular the ones that claim to be committed to women and minority empowerment.

Further work should also assess the impact of gender on creditworthiness through a careful examination of default history (Ferguson and Peters, 1997). If women do indeed exhibit lower default rates, as often claimed by the micro- 
credit industry and confirmed by Marrez and Schmit (2009) who study a Moroccan MFI, then the presence of taste-based discrimination, as opposed to profit-based statistical discrimination, would become undeniable. As pointed out by Ladd (1998), very little information exists on default rates. Therefore, we strongly encourage regulators, donors, and other recommendation issuers to request the release of detailed data from the MFIs.

Viewed through the women empowerment lens, our results are consistent with two dominant, but seemingly contradictory, features found in the literature. On the one hand, as far as access to credit is concerned, women are treated on the same grounds as men. Therefore, microcredit does indeed offer unexplored opportunities to female entrepreneurs. But on the other hand, women keep facing harsher conditions than men regarding not only their social and familial statuses, but also their borrowing possibilities. In that perspective, our results extend to credit conditions the mitigated conclusions on women empowerment reached by Kabeer (2001).

Furthermore, as small loans are known to be less profitable (Armendáriz and Morduch, 2010), the number of women benefiting from microcredit could progressively decline in profit-oriented MFIs (Cull et al., 2006). In that line, our results confirm the findings by, e.g., Johnson (2004) and Corsi et al. (2006) that a gender-sensitive approach makes sense in the microfinance industry.

Lastly, the scope of this paper goes beyond microcredit and gender issues. Actually, our model is applicable to any kind of taste-based discrimination in lending. The current literature is mostly focused on denial (or approval) rate. We show that examining loan size may reveal insightful as well. Getting a required loan is good news for an entrepreneur, but when it comes to investing it for business purposes, the loan size matters more. 


\section{References}

Ahmed, Ali M. 2007. "Group identity, social distance and intergroup bias." Journal of Economic Psychology, 28(3): 324-337.

Alesina, Alberto F., Francesca Lotti, and Paolo Emilio Mistrulli. 2008. "Do Women Pay More for Credit? Evidence from Italy." National Bureau of Economic Research Working Paper Series 14202.

Armendariz, Beatriz, and Ariane Szafarz. 2009. "On Mission Drift In Microfinance Institutions." Université Libre de Bruxelles CEB-WP 09-015. Forthcoming in B. Armendariz and M. Labie (eds), \textitThe Handbook of Microfinance, London-Singapore: World Scientific Publishing.

Armendáriz, Beatriz, and Jonathan Morduch. 2010. The Economics of Microfinance. 2 ed. Cambridge, MA:The MIT Press.

Barber, Brad M., and Terrance Odean. 2001. "Boys Will be Boys: Gender, Overconfidence, and Common Stock Investment." Quarterly Journal of Economics, 116(1): 261-292.

Becker, Gary S. 1971. The Economics of Discrimination. 2nd ed. University of Chicago Press.

Bellucci, Andrea, Alexander Borisov, and Alberto Zazzaro. 2009. "Does Gender Matter in Bank-Firm Relationships? Evidence from Small Business Lending." Univ. Politecnica Marche Money and Finance Research group Working Papers 31.

Biggs, Tyler, Mayank Raturi, and Pradeep Srivastava. 2002. "Ethnic networks and access to credit: evidence from the manufacturing sector in Kenya." Journal of Economic Behavior \&6 Organization, 49(4): 473-486.

Blanchard, Lloyd, Bo Zhao, and John Yinger. 2008. "Do lenders discriminate against minority and woman entrepreneurs?" Journal of Urban Economics, 63(2): 467-497.

Blanchflower, David G., Phillip B. Levine, and David J. Zimmerman. 2003. "Discrimination in the Small-Business Credit Market." Review of Economics and Statistics, 85(4): 930-943.

Borghans, Lex, Bart Golsteyn, James J. Heckman, and Huub Meijers. 2009. "Gender Differences in Risk Aversion and Ambiguity Aversion." IZA Discussion Paper 3985. 
Bostic, Raphael. 2003. "A Test of Cultural Affinity in Home Mortgage Lending." Journal of Financial Services Research, 23(2): 89-112.

Buttner, E. Holly, and Benson Rosen. 1988. "Bank loan officers' perceptions of the characteristics of men, women, and successful entrepreneurs." Journal of Business Venturing, 3(3): 249-258.

Buvinic, Mayra, and Marguerite Berger. 1990. "Sex differences in access to a small enterprise development fund in Peru." World Development, 18(5): 695-705.

Carter, David A., Betty J. Simkins, and W. Gary Simpson. 2003. "Corporate Governance, Board Diversity, and Firm Value." Financial Review, 38(1): 33-53.

Carter, Nancy, Candida Brush, Patricia Greene, Elizabeth Gatewood, and Myra Hart. 2003. "Women entrepreneurs who break through to equity financing: the influence of human, social and financial capital." Venture Capital: An International Journal of Entrepreneurial Finance, 5(1): 1-28.

Carter, Sara, Eleanor Shaw, Wing Lam, and Fiona Wilson. 2007. "Gender, entrepreneurship, and bank lending: the criteria and processes used by bank loan officers in assessing applications." Entrepreneurship Theory and Practice, 31(3): 427-444.

Caudill, Steven B., Daniel M. Gropper, and Valentina Hartarska. 2009. "Which Microfinance Institutions Are Becoming More Cost Effective with Time? Evidence from a Mixture Model." Journal of Money, Credit and Banking, 41(4): 651-672.

Cavalluzzo, Ken, and John Wolken. 2005. "Small Business Loan Turndowns, Personal Wealth, and Discrimination." Journal of Business, 78(6): 2153-2178.

Cavalluzzo, Ken, and Linda Cavalluzzo. 1998. "Market Structure and Discrimination: The Case of Small Businesses." Journal of Money, Credit and Banking, 30(4): 771-92.

Corsi, Marcella, Fabrizio Botti, Tommaso Rondinella, and Giulia Zacchia. 2006. "Women and Microfinance in Mediterranean Countries." Development, 49(2): 67-74. 
Cull, Robert, Lance E. Davis, Naomi R. Lamoreaux, and JeanLaurent Rosenthal. 2006. "Historical financing of small- and mediumsize enterprises." Journal of Banking \&6 Finance, 30(11): 3017-3042.

Daley-Harris, Sam. 2009. "State of the Microcredit Summit Campaign Report." Microcredit Summit Campaign, Washington, D.C.

Erhardt, Niclas L., James D. Werbel, and Charles B. Shrader. 2003. "Board of Director Diversity and Firm Financial Performance." Corporate Governance, 11(2): 102-111.

Fein, S, and S.J. Spencer. 1997. "Prejudice as Self-Image Maintenance: Affirming the Self Through Derogating Others." Journal of Personality and Social Psychology, 73: 44, 31.

Ferguson, Michael F., and Stephen R. Peters. 1997. "Cultural Affinity and Lending Discrimination: The Impact of Underwriting Errors and Credit Risk Distribution on Applicant Denial Rates." Journal of Financial Services Research, 11(1): 153-168.

Fischer, Eileen M., A. Rebecca Reuber, and Lorraine S. Dyke. 1993. "A theoretical overview and extension of research on sex, gender, and entrepreneurship." Journal of Business Venturing, 8(2): 151-168.

Fletschner, Diana. 2009. "Rural Women's Access to Credit: Market Imperfections and Intrahousehold Dynamics." World Development, 37(3): 618631.

Garikipati, Supriya. 2008. "The Impact of Lending to Women on Household Vulnerability and Women's Empowerment: Evidence from India." World Development, 36(12): 2620-2642.

Goetz, Anne Marie, and Rina Sen Gupta. 1996. "Who takes the credit? Gender, power, and control over loan use in rural credit programs in Bangladesh." World Development, 24(1): 45-63.

Guérin, Isabelle, Marc Roesch, Venkatasubramanian, Mariam Sangare, and Santosh Kumar. 2009. "Microfinance and the dynamics of financial vulnerability. Lessons from rural South India." RuMe Working Paper.

Guérin, Isabelle, Roy Mersland, and Bert D'Espallier. 2009. "Gender bias in microfinance." RuMe Working Paper. 
Haines, G.H., B.J. Orser, and A.L. Riding. 1999. "Myths and Realities: An Empirical Study of Banks and the Gender of Small Business Clients." Canadian Journal of Administrative Sciences / Revue Canadienne des Sciences de l'Administration, 16(4): 291-307.

Han, Song. 2004. "Discrimination in Lending: Theory and Evidence." Journal of Real Estate Finance and Economics, 29(1): 5-46.

Hartarska, Valentina. 2005. "Governance and Performance of Microfinance Institutions in Central And Eastern Europe and the Newly Independent States." World Development, 33(10): 1627-1643.

Hashemi, Syed M., Sidney Ruth Schuler, and Ann P. Riley. 1996. "Rural credit programs and women's empowerment in Bangladesh." World Development, 24(4): 635-653.

Helland, Inge S. 1990. "Partial Least Squares Regression and Statistical Models." Scandinavian Journal of Statistics, 17(2): 97-114.

Hudon, Marek. 2009. "Should Access to Credit be a Right?" Journal of Business Ethics, 84(1): 17-28.

Hunter, William C, and Mary Beth Walker. 1996. "The Cultural Affinity Hypothesis and Mortgage Lending Decisions." Journal of Real Estate Finance and Economics, 13(1): 57-70.

ILO. 2009. "Small Change, Big Changes: Women and Microfinance." International Labour Organization, Geneva.

Jianakopolos, Nancy Ammon, and Alexandra Bernasek. 1998. "Are women more risk averse ?" Economic Inquiry, 36(4): 620-630.

Johnson, Susan. 2004. "Gender Norms in Financial Markets: Evidence from Kenya." World Development, 32(8): 1355-1374.

Kabeer, Naila. 2001. "Conflicts Over Credit: Re-Evaluating the Empowerment Potential of Loans to Women in Rural Bangladesh." World Development, 29(1): 63-84.

Kanter, Rosabeth Moss. 1993. Men and Women of the Corporation. 2 ed. New York:Basic Books. First Edition: 1977.

Khandker, Shahidur R, Baqui Khalily, and Zahed Khan. 1995. Grameen Bank: Performance and Sustainability. World Bank discussion paper no.306 Washington, D.C.:World Bank. 
Kunda, Ziva, and Lisa Sinclair. 1999. "Motivated Reasoning with Stereotypes: Activation, Application, and Inhibition." Psychological Inquiry, 10(1): 12-22.

Labie, Marc, Pierre-Guillaume Méon, Roy Mersland, and Ariane Szafarz. 2010. "Discrimination by Microcredit Officers: Theory and Evidence on Disability in Uganda." Université Libre de Bruxelles CEB-WP 10-007.

Lacour-Little, Michael. 1999. "Discrimination in Mortgage Lending: A Critical Review of the Literature." Journal of Real Estate Literature, $7(1): 15-50$.

Ladd, Helen F. 1998. "Evidence on Discrimination in Mortgage Lending." Journal of Economic Perspectives, 12(2): 41-62.

Marrez, Helena, and Mathias Schmit. 2009. "Credit risk analysis in microcredit: How does gender matter?" Université Libre de Bruxelles CEB-WP 09-053.

Mayoux, Linda. 2002. "Microfinance and women's empowerment: Rethinking best practice." Development Bulletin, 57: 76-81.

McKim, Andrew, and Matthew Hughart. 2005. "Staff Incentive Schemes in Practice: Finding of a Global Survey of Microfinance Institutions." MicroFinance Network, CGAP.

Morduch, Jonathan. 1999. "The Microfinance Promise." Journal of Economic Literature, 37(4): 1569-1614.

Munnell, Alicia H., Geoffrey M. B. Tootell, Lynn E. Browne, and James McEneaney. 1996. "Mortgage Lending in Boston: Interpreting HMDA Data." American Economic Review, 86(1): 25-53.

Olsen, Robert A., and Constance M. Cox. 2001. "The Influence of Gender on the Perception and Response to Investment Risk: The Case of Professional Investors." Journal of Psychology and Financial Markets, 2(1): 29-36.

Pitt, Mark M, Shahidur R Khandker, and Jennifer Cartwright. 2006. "Empowering Women with Micro Finance: Evidence from Bangladesh." Economic Development and Cultural Change, 54(4): 791831. 
Ross, Stephen L. 2000. "Mortgage Lending, Sample Selection and Default." Real Estate Economics, 28(4): 581-621.

Schafer, Robert, and Helen F Ladd. 1982. Discrimination in Mortgage Lending. Harvard-MIT Joint Center for Urban Studies Series Cambridge, MA:MIT Press.

Sexton, Donald L., and Nancy Bowman-Upton. 1990. "Female and male entrepreneurs: Psychological characteristics and their role in genderrelated discrimination." Journal of Business Venturing, 5(1): 29-36.

Sheriff, Robin E. 2000. "Exposing Silence as Cultural Censorship: A Brazilian Case." American Anthropologist, 102(1): 114-132.

Stiglitz, Joseph E, and Andrew Weiss. 1981. "Credit Rationing in Markets with Imperfect Information." American Economic Review, 71(3): 393410.

Storey, D. 2004. "Racial and Gender Discrimination in the Micro Firms Credit Market?: Evidence from Trinidad and Tobago." Small Business Economics, 23(5): 401-422.

Szafarz, Ariane. 2008. "An alternative to statistical discrimination theory." Economics Bulletin, 10(5): 1-6.

Tenenhaus, M. 1998. La Régression PLS: Théorie et Pratique. Paris:Technip.

Turner, Margery Austin, and Felicity Skidmore. 1999. Mortgage Lending Discrimination: A Review of Existing Discrimination. U.S. Department of Housing and Urban Development.

Weller, Christian E. 2009. "Credit Access, the Costs of Credit and Credit Market Discrimination." Review of Black Political Economy, 36(1): 7-28.

Wold, S., A. Ruhe, H. Wold, and W. J. Dunn. 1984. "The Collinearity Problem in Linear Regression. The Partial Least Squares (PLS) Approach to Generalized Inverses." SIAM Journal on Scientific and Statistical Computing, 5(3): 735-743.

Zycher, B., and T.A. Wolfe. 1994. "Mortgage Lending, Discrimination, and Taxation." Regulation, 17(2): 61-73. 


\section{Appendix A Descriptive Statistics by Credit Of- ficer's Gender}

Table 10: Portfolio comparison with respect to credit officer's gender

\begin{tabular}{lccc}
\hline \multicolumn{1}{c}{ Credit Officers } & Female & Male & t-test $^{c}$ \\
\hline Female Applicant & 0.512 & 0.480 & $0.0317 * * *$ \\
Requested Amount (BRL) & 1395.7 & 1380.2 & 15.43 \\
Proposed Amount (BRL) & 999.0 & 1065.3 & $-66.31 * * *$ \\
Loan Size (BRL) & 976.7 & 1049.2 & $-72.49 * * *$
\end{tabular}

Applicant characteristics

\begin{tabular}{|c|c|c|c|}
\hline At least one dependent ${ }^{b}$ & 0.515 & 0.529 & $-0.0136 *$ \\
\hline Married client ${ }^{b}$ & 0.483 & 0.470 & $0.0126 *$ \\
\hline Age (in years) & 42.83 & 41.89 & $0.932 * * *$ \\
\hline come (BRL) & 190.2 & 242.4 & $-52.29 * * *$ \\
\hline at Vivacred & 2.157 & 2.448 & $-0.291 * * *$ \\
\hline \# former loans with delay & 0.0305 & 0.0363 & $-0.00577 * *$ \\
\hline \# times as a guarantor & 0.632 & 0.867 & $-0.235 * * *$ \\
\hline
\end{tabular}

\section{Credit characteristics}

\begin{tabular}{lccc}
\hline \# installments & 9.008 & 9.064 & -0.0558 \\
Investment purpose $^{b}$ & 0.324 & 0.317 & 0.00713 \\
Loan repayment purpose $^{b}$ & 0.101 & 0.0883 & $0.0129 * * *$ \\
Guarantor's involvement $^{b}$ & 0.946 & 0.917 & $0.0291 * * *$
\end{tabular}

Business characteristics

\begin{tabular}{lccc}
\hline Business profit (BRL) & 954.8 & 907.2 & $47.65 * *$ \\
Sector (trade $=1$ ) & 0.552 & 0.508 & $0.0437 * * *$ \\
Official business $^{b}$ & 0.0567 & 0.0597 & -0.00301 \\
\# of employees & 0.680 & 0.584 & $0.0968 * * *$ \\
\hline
\end{tabular}

${ }^{a}$ Dummy variable: Yes $=1$, No $=0$

${ }^{c}$ t-test for equal means between genders $* * * \mathrm{p}<0.01,{ }^{* *} \mathrm{p}<0.05,{ }^{*} \mathrm{p}<0.1$ 


\section{Appendix B Robustness check for the glass ceil- ing effect}

The robustness check is based on a third specification for the loan size regression. Namely, we split the full sample in two subsamples according to requested amount (cut-off at the mean ${ }^{32}$ ) and estimate equation (16) on each subsample, separately. Moreover, we run the same regressions on each subsample being itself split by officer's gender. In that way, we isolate the female and male officers' behaviors when facing tiny versus small loan requests.

All estimates are given in table 11. Table 12 complements these results with Chow tests for comparing coefficients of the two regressions. Globally, the presence of a glass ceiling is confirmed in all subsamples (all applications, applications attended by male officers, applications attended by female officers). Regarding the differential treatment of tiny and small requests, male and female credit officers tend to adopt contrasting strategies, confirming the findings in section 6 .

Table 11: Loan size regression: Third specification for glass ceiling detection

\begin{tabular}{lccc|ccc}
\hline Subsample & \multicolumn{3}{c|}{ Requests $<$ Average } & \multicolumn{3}{c}{ Requests $\geq$ Average } \\
Officer's gender & All & Male & Female & All & Male & Female \\
\hline & $(1)$ & $(2)$ & $(3)$ & $(4)$ & $(5)$ & $(6)$ \\
\hline $\mathrm{F}$ & $-63.70^{* * *}$ & $-54.21^{* * *}$ & $-69.38^{* * *}$ & $59.02^{* * *}$ & $41.15^{*}$ & $99.03^{* * *}$ \\
& $(5.788)$ & $(7.560)$ & $(8.734)$ & $(17.33)$ & $(23.30)$ & $(25.49)$ \\
RRA & $0.699^{* * *}$ & $0.703^{* * *}$ & $0.668^{* * *}$ & $0.633^{* * *}$ & $0.637^{* * *}$ & $0.627^{* * *}$ \\
& $(0.00614)$ & $(0.00791)$ & $(0.00958)$ & $(0.00808)$ & $(0.0103)$ & $(0.0127)$ \\
RRA * F & 0.00999 & -0.00416 & $0.0287^{* *}$ & $-0.205^{* * *}$ & $-0.146^{* * *}$ & $-0.287^{* * *}$ \\
& $(0.00848)$ & $(0.0114)$ & $(0.0125)$ & $(0.0133)$ & $(0.0174)$ & $(0.0202)$ \\
\hline Controls & All & All & All & All & All & All \\
Observations & 20769 & 10836 & 9933 & 13081 & 6751 & 6330 \\
R-squared & 0.736 & 0.781 & 0.701 & 0.707 & 0.760 & 0.642 \\
\hline \multicolumn{3}{c}{ Standard errors in parentheses; ${ }^{* * *} \mathrm{p}<0.01,{ }^{* *} \mathrm{p}<0.05,{ }^{*} \mathrm{p}<0.1$}
\end{tabular}

\footnotetext{
${ }^{32}$ As the mean requested amount is BRL 1014, or approximately USD 576, we prefer to refer to the corresponding types of loan as "tiny" and "small", rather than "small" and "large".
} 
Table 12: Chow tests for comparing the columns of table 11

\begin{tabular}{lccc|cc}
\hline Chow test for & \multicolumn{3}{c|}{ Presence of glass ceiling } & \multicolumn{2}{c}{ Impact of officer's gender } \\
Sample & All officers & Male officers & Female officers & Tiny requests & Small requests \\
Table 11 col. & $(1)-(4)$ & $(2)-(5)$ & $(3)-(6)$ & $(2)-(3)$ & $(5)-(6)$ \\
\hline Diff. F & $-122.7^{* * *}$ & $-95.36^{* * *}$ & $-168.4^{* * *}$ & -15.17 & $57.88^{*}$ \\
Diff. RRA & $(16.29)$ & $(22.03)$ & $(23.90)$ & $(11.53)$ & $(34.48)$ \\
& $0.0666^{* * *}$ & $0.0668^{* * *}$ & $0.0412^{* *}$ & $-0.0353^{* * *}$ & -0.00970 \\
Diff. RRA * F & $(0.0132)$ & $(0.0177)$ & $(0.0198)$ & $(0.0123)$ & $(0.0163)$ \\
& $0.215^{* * *}$ & $0.142^{* * *}$ & $0.316^{* * *}$ & $0.0329^{*}$ & $-0.141^{* * *}$ \\
& $(0.0188)$ & $(0.0262)$ & $(0.0271)$ & $(0.0170)$ & $(0.0266)$ \\
\hline \multicolumn{5}{c}{ Standard errors in parentheses; ${ }^{* * *} \mathrm{p}<0.01,{ }^{* *} \mathrm{p}<0.05,{ }^{*} \mathrm{p}<0.1$} \\
\end{tabular}

For tiny requests (below the mean), the gender gap attributable to male officers does not increase with respect to project scale. The interaction term between the client's gender and the requested amount is indeed not significant. Surprisingly, the corresponding female officers' regression exhibits a negative gender dummy coefficient, but a positive interaction term coefficient. This means that, for the tiny requests, the loan size proposed to women by female officers increases with respect to the requested amount, but with a constant handicap. Thus, female credit officers partially compensate the female borrowers' gap (that they create), but only for "low-medium" requests (i.e., the highest tiny requests). For small requests (above the mean), the opposite is observed. For all officers, the gender dummy is positive, but more than compensated by a negative interaction term. Female officers are especially penalizing to the female applicants introducing the highest requests.

In summary, the results confirm the presence of a glass ceiling but highlight the non linearity of the relationship between requested amount and loan size. This is likely due to the fact that requests are not objective data like the applicant's personal characteristics. Indeed, the requested amount may result from a strategic behavior from the applicant. Manipulating tiny requests is often pointless, but the stake becomes more meaningful for more ambitious applicants. If this argument holds, then the results would mean that female applicants with higher requests lack credibility in front of all credit officers, and especially female ones. 